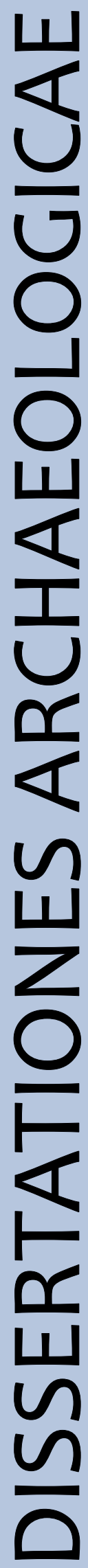

ex Instituto Archaeologico Universitatis de Rolando Eötvös nominatae
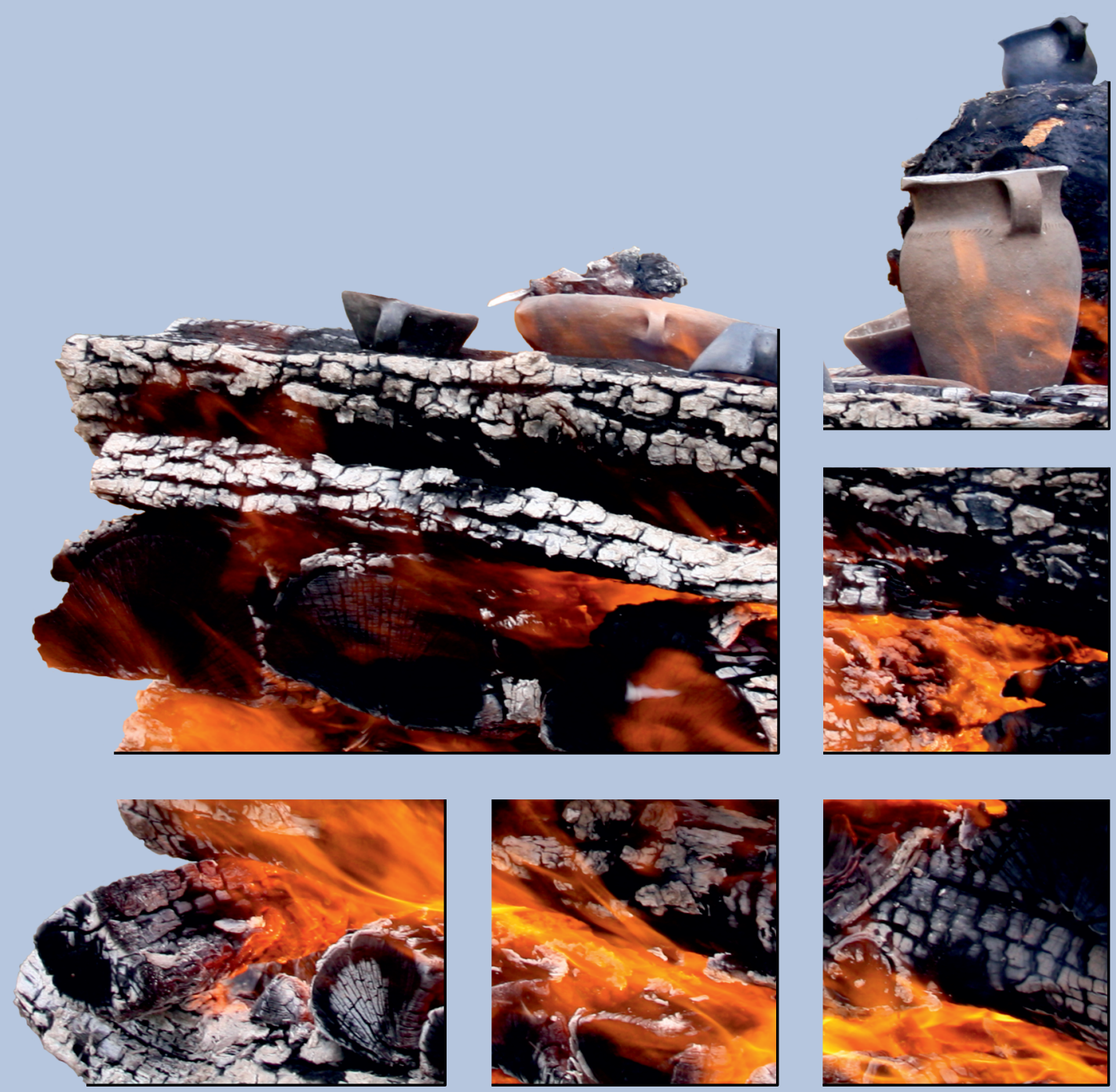

$$
\text { Ser。 3. No } 0_{0} \sigma_{0} \mid 2018
$$




\section{Dissertationes Archaeologicae ex Instituto Archaeologico}

Universitatis de Rolando Eötvös nominatae Ser. 3. No. 6.

Budapest 2018 


\section{Dissertationes Archaeologicae ex Instituto Archaeologico}

Universitatis de Rolando Eötvös nominatae Ser. 3. No. 6.

Editor-in-chief:

DÁvid BARTUS

Editorial board:

LÁsZló BARTOSIEWICZ

LÁSZLÓ BORHY

ZOLTÁN CZAJLIK

ISTVÁN FELD

GÁBOR KALLA

PÁL RACZKY

MiKLÓS SZABÓ

Tivadar Vida

Technical editor:

GÁBOR VÁcZI

Proofreading:

ZsófIA KondÉ

SzILVIA BARTUS-SzÖLLősI

Aviable online at http://dissarch.elte.hu

Contact: dissarch@btk.elte.hu

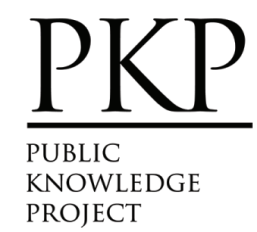

๑ E Eötvös Loránd University, Institute of Archaeological Sciences

Layout and cover design: Gábor Váczi

Budapest 2018 


\section{CONTENTS}

Zsolt Mester

In memoriam facques Tixier (1925-2018)

\section{ARTICLES}

Katalin SEBőK

On the possibilities of interpreting Neolithic pottery - Az újkökori kerámia értelmezési lehetőségeiről

András FüZESI - Pál RACZKY

Öcsöd-Kováshalom. Potscape of a Late Neolithic site in the Tisza region

Katalin SEBőK - Norbert FARAgó

Theory into practice: basic connections and stylistic affiliations of the Late Neolithic settlement at Pusztataskony-Ledence 1

Eszter Solnay

Early Copper Age Graves from Polgár-Nagy-Kasziba

László GuCsi - Nóra Szabó

Examination and possible interpretations of a Middle Bronze Age structured deposition

Kristóf FÜLÖP

Why is it so rare and random to find pyre sites? Two cremation experiments to understand the characteristics of pyre sites and their investigational possibilities

Gábor János TARBAY

"Looted Warriors" from Eastern Europe

Péter MogYoRós

Pre-Scythian burial in Tiszakürt

Szilvia JoHÁczi

A New Method in the Attribution? Attempts of the Employment of Geometric Morphometrics in the Attribution of Late Archaic Attic Lekythoi 
The Roman aqueduct of Brigetio

Lajos JuHÁsz

A republican plated denarius from Aquincum

Barbara HAJDU

Terra sigillata from the territory of the civil town of Brigetio

Krisztina HoppÁL - István VIDA - Shinatria AdHityatAma - Lu Yahui 461

'All that glitters is not Roman'. Roman coins discovered in East Java, Indonesia.

A study on new data with an overview on other coins discovered beyond India

\section{FIELD REPORTS}

Zsolt MESTER - Ferenc CSERPÁK - Norbert FARAGÓ

Preliminary report on the excavation at Andornaktálya-Marinka in 2018

Kristóf FÜLÖP - Denisa M. LÖNHARDT - Nóra SZABÓ - Gábor VÁcZI

Preliminary report on the excavation of the site Tiszakürt-Zsilke-tanya

Bence Simon - Szilvia JohÁcZI - Zita KIS

Short report on a rescue excavation of a prehistoric and Árpádian Age site near Tura

(Pest County, Hungary)

Zoltán CzAJlik - Katalin NovinszKi-Groma - László RupNIK - András BöDőcs - et al. 527

Archaeological investigations on the Süttö plateau in 2018

Dávid BARTus - László BORHY - Szilvia JoHÁczi - Emese SzÁMADó

Short report on the excavations in the legionary fortress of Brigetio (2017-2018)

Bence Simon - Szilvia JoháczI

Short report on the rescue excavations in the Roman Age Barbaricum near Abony

(Pest County, Hungary)

Szabolcs Balázs NAGY

Recent excavations at the medieval castle of Bánd 


\section{Thesis Abstracts}

Rita JENEY

Lost Collection from a Lost River: Interpreting Sir Aurel Stein's "Sarasvatī Tour" in the History of South Asian Archaeology

István VIDA

The Chronology of the Marcomannic-Sarmatian wars. The Danubian wars of Marcus Aurelius in the light of numismatics

Zsófia MASEK

Settlement History of the Middle Tisza Region in the $4^{\text {th }}-6^{\text {th }}$ centuries AD.

According to the Evaluation of the Material from Rákóczifalva-Bagi-földek 5-8-8A sites

Alpár Doвоs

Transformations of the human communities in the eastern part of the Carpathian Basin between the middle of the $5^{\text {th }}$ and $7^{\text {th }}$ century. Row-grave cemeteries in Transylvania, Partium and Banat 


\title{
A New Method in Attribution? Attempts of the Employment of Geometric Morphometrics in the Attribution of Late Archaic Attic Lekythoi
}

\author{
SzILVIA JoHÁcZI \\ Institute of Archaeological Sciences \\ Eötvös Loránd University \\ johi.sziszi@gmail.com
}

\begin{abstract}
:
In the Late Archaic - Early Classic period, the Attic ceramic industry was characterized by a kind of duality. On the one hand, the red-figure technique was flourishing, when Euphronios', Douris' or the Berlin Painter's works represented the height of Greek vase painting. On the other hand, the market was also covered by large quantities of low-quality black-figure pottery. Not only in Athens, but even in the whole Ancient Mediterranean these mass-produced vessels emerge constantly, even from modern excavations. Therefore, in contrast to most vases of more talented painters they can be attached to an archaeological feature or layer. Due to their inadequate style, relatively few characteristics can be determined while looking at the painting. Thus, the manufacturing criteria, such as the details of the shapes, are more important in the attribution. In this paper, I study the late black-figure lekythoi of the Museum of Fine Arts in Budapest with the help of geometric morphometrics using $3 D$ reconstructions.
\end{abstract}

\section{The Feasibility and Limits of Beazley's Method}

It is well known that a complicated and multifactorial system is needed to ascertain a vase painter based solely on their work. This is even more problematic in the case of late black-figure vases. Due to their inferior quality (etched details are rough and few, the paintwork is mediocre, etc.), it is difficult to recognize their characteristics based on the details.Thus in attributing these vases, the theme, composition, and the vase form are far more significant. Therefore it can easily be realized that the majority of the black-figure vases made in the first half of the $5^{\text {th }}$ century BC can only be referred to certain groups. ${ }^{1}$

Beazley himself acknowledged his scruples concerning late black-figure pottery in his letters during the preparation of Attic Black-Figure Vase Painters. ${ }^{2}$ As Dietrich von Bothmer remembered in the opus released for the centenary of Beazley's birth, this great master of painter attribution often complained about one of the iconic figures of the era, "the Haimon Painter and other lekythoi". ${ }^{3}$ Even Caroline Henriette Emilie Haspels, who has laid the foundations for the attribution and classification of late black-figure lekythoi, states at the beginning of her chapter about the Haimon Painter that even though this painter played a central role in the black-figure pottery industry of the first half of the $5^{\text {th }}$ century $\mathrm{BC}$, his style is "difficult to

1 It is well demonstrated by the example of the Haimon Painter: only a small number of vases can be directly attributed to him in comparison to the closely linked Haimon Group, which consists of a large quantity of material (JUBIER-GALINIER 2016, 130).

2 BeAzley 1956.

3 BOTHMER 1985, 15. 
tackle". ${ }^{4}$ An additional problem is that later on in the $5^{\text {th }}$ century $\mathrm{BC}$, it seems as if these barely attributable painters and workshops merged together. ${ }^{5}$

We can call into question if it is worth the time to attribute these mass produced wares, which are better known by the repeat of iconographic schemata than any significant innovation in technique or style. The answer is most definitely 'yes', although the reason is not attribution for the sake of attribution, but the fact itself that these vases are the results of mass production. Thus, they can be found in graves, sanctuaries, different urban settings in Athens, Attica, in all of Hellas ${ }^{6}$ and even beyond: they are constantly found in modern excavations in the Ancient Mediterranean and the peripheries of the Hellenic world. ${ }^{7}$ According to the data in the Beazley Archive ${ }^{8} 673$ pieces are currently attributed to the Haimon Group, 383 to the Diosphos Painter, 356 to the Beldam Painter, while only 117 to Exekias and 198 to the Amasis Painter. The difference might even be greater, since it is common for some Museums to only upload the larger, better quality vases to the Beazley Archive, while overlooking the smaller lekythoi which are of inferior quality - hence, the result is a rather disproportionate database. Whereas it can safely be assumed that all of the known works of Exekias or the Amasis Painter are in the Archive, we cannot say the same about the vases of the Haimon Group or those belonging to the Beldam Painter, let alone the fragments. To gain a deeper understanding of the Attic ceramic industry of the era regarding production and market, this large quantity of material will have to be attributed, located in time, and placed within the wider network of Attic black-figure pottery. ${ }^{9}$

\section{The Prospects of Geometric Morphometrics}

Modern researchers agree that the cornerstones of attribution when it comes to Late Archaic and Early Classic lekythoi are the details of their shape. When paying attention to these details, we are essentially attempting to determine certain potters, reconstructing a theoretical workshop connected to them. Only later, if we are lucky, may we identify a painter or a group. ${ }^{10}$ The main evidence for this is Kurtz's typology of the most characteristic shapes pertaining to a vase-painter in Athenian White Lekythoi, thus creating the types BL (Bowdoin Painter Lekythoi), ${ }_{11}^{11}$ DL (Diosphos Painter Lekythoi), ${ }^{12}$ PL (Petit Palais 336 Painter Lekythoi), ${ }^{13}$ ATL (Aeschines and Tymbolos Painter Lekythoi), ${ }^{14}$ CL (Carlsruhe Painter Lekythoi), ${ }^{15}$ and BEL (Beldam Painter Lekythoi). ${ }^{16}$

4 HASPELS 1936, 130.

5 JUBIER-Galinier 2003, 79.

6 JUBIER-GALINIER 2016, 130.

7 A good example for that is the Lancut Group, which was isolated within the Haimon Group by Beazley himself, and consists predominantly of slender skyphoi and other drinking vessels made with silhouette-technique (Morgan 2004, 200). What is interesting about this group is that these vases can be found everywhere on the periphery of the Mediterranean: Israel, Northern Italy, the northern part of the Aegean, Thrace, Macedonia, the Middle and Southern Adriatic, and even in the northern shore of the Black Sea, the Crimea, and the valley of the Kuban River (SHEFTON 1999).

8 http://www.beazley.ox.ac.uk. As of 5 March 2018.

9 JUBier-GALINIER 2016, 130.

10 Comp. Haspels 1936, and Kurtz 1975.

11 Kurtz 1975, 79.

12 Kurtz 1975, 80-81.

13 Kurtz 1975, 81.

14 Kurtz 1975, 82-83.

15 Kurtz 1975, 84.

16 KuRTZ 1975, 84-87. 
These types are defined by several criteria: a certain kind of mouth, foot, shoulder or body, or other characteristics such as the Bedlam Painter's horizontal line at the bottom of the body, etched in the still wet clay. However, these criteria are not always realized together: there are exceptions from the rule which make manual classification more difficult and thus confuse the viewer. In consequence, identification through mere inspection contains too many subjective elements, which results in an exceptionally large number of unattributed vases. It is therefore legitimate to ask whether the digital achievements such as $3 \mathrm{D}$ reconstruction and the analytical methods using it could help the attribution.

The approach used to compare the shapes of two- or three-dimensional structures is called geometric morphometrics. To (programmatically) analyse real-life objects in virtual space they have to be represented in a way that preserves relevant information. Modern morphometrics provides two state of the art methods to address this: landmark configuration and outline analysis. ${ }^{17}$ Landmark configuration is a point-based analytic method. To apply it, characteristic structural elements of the object have to be determined (these are the landmarks themselves), recreated and fixed in a coordinate system, on which the comparison will be based. A prerequisite for this method is that the shapes to be compared should have the homologous and equal number of landmarks. If that does not or only partly applies, landmark configuration is less suitable. For example, this method can be ideal in anthropology or archaeozoology, where the human or animal bones of the same type have the same number of breakpoints in the exact same places, which are easy to observe and are representative of the object due to their (biological/anatomical) function. However, vases present a completely different and more problematic area: they are man-made, diverse, with a lot of flaws and malformations. Moreover, the majority had been broken and restored over time, which compromises their form even further. Thus, only a very few fix landmarks can be taken on them, which might not be sufficient to determine the parameters of the vase. On the other hand, using the other method, outline analysis, we examine the outline of the object, which is defined here as the closed polygon formed by the $(x ; y)$ coordinates of the consisted pixels defining it. ${ }^{18}$ After employing both methods, the latter proved to be more useful for my analysis.

In the January of 2018 I have had the opportunity ${ }^{19}$ to use an Artec Space Spider 3D scanner, which is a high-resolution 3D scanner that uses blue light technology. The scanner is small (weighing only $0.85 \mathrm{~kg}$ ), and is capable of scanning tiny, more detailed objects with $0.1 \mathrm{~mm}$ accuracy and an error margin of $0.05 \mathrm{~mm}$. While working, it records with 7.5 frames per second, which it immediately aligns in space. The device is operated by using a software developed for this particular hardware family called Artec Studio, ${ }^{20}$ providing a real-time ability to supervise and control the scanning process. ${ }^{21}$ To fully digitize an object, multiple scans are needed which can be aligned and merged using the software, and afterwards a 3D model can be created which can be exported in various formats. ${ }^{22}$

The device not only records the shape, but also the texture of the object in $1.3 \mathrm{mp}$, which is

17 BonHomme et al. 2014, 3.

18 Bonhomme et al. 2014, 4.

19 I would like to express my gratitude to András Patay-Horváth $\mathrm{PhD}$, senior lecturer of the Department of Classical Studies at the Eötvös Loránd University of Budapest, for making the scanner available for me to use.

20 I have used Artec Studio 9.

21 https://www.artec3d.com/files/pdf/Space-Spider-Booklet-EURO.pdf

22 The following formats are available: obj, ply, wrl, stl, aop, ascoo, ptx, e57, xyzrgb. 
most advantageous. ${ }^{23}$ This way, as we scan a vase, the model gives us even more information to work with than just the form. On the one hand, we can have an exact cross-section of the object instead of a manually drawn section plan, and on the other hand, laying out the texture the iconography of the painting becomes more visible and better examinable - as it is the same (but more accurate) image than a hand-drawn one. ${ }^{24}$ This method is also capable of measuring the surface of an object, thus - geometric morphometrics.

Completing this article I have only had the time and the possibility to work with the pieces currently in the Museum of Fine Arts in Budapest. With the previously described device I have managed to digitize 30 whole (or fully completed from fragments) Attic lekythoi from the Antique Collection, all of them dated between 510 and $450 \mathrm{BC},{ }^{25}$ of various styles. After careful examination, I have excluded squat lekythoi from the analysis, as their shape is radically different from the others (almost as if it was a separate form).

After I finished creating the 3D models, I positioned all of them in a coordinate system: the vertical centreline of each lekythos was adjusted to the $y$ axis, while the ear was aligned with the positive direction of the $x$ axis. To perform the geometric morphometrics, I have sectioned the surface along the $y z$ plane, thus ignoring the ear as it would have compromised the results in a negative way.

\section{Full Profile Examination - Outline Analysis}

First I intended to perform the outline analysis, therefore I have exported the results of the intersection in dxf file format, then converted it into an image in AutoCAD, which I then exported as a jpeg file since the software called $R,{ }^{26}$ which is capable of different statistical analyses (such as geometric morphometrics), only supported this format. I used the Momocs package of the software for outline analysis, which lets the user complete the analysis without landmarks, only examining the outline. ${ }^{27} \mathrm{I}$ have excluded the restored pieces, as well as vases with missing foot or mouth, in order not to have the results compromised by these details. This selection has left me 30 lekythoi to work with.

The jpeg/jpg files were imported into the $R$ program and closed polygons approximating the outlines were calculated by utilizing the Momocs package. Data was examined first with factor analysis first, which showed the relative variances through 30 , monotonically decreasing axes (74.86\%, $11.93 \%, 3.88 \%, 3.14 \%, 1.64 \%$ and further 25 pieces). The first four axes contain $93.8 \%$ of the full data collection's variance, therefore those can be seen as significant and relevant regarding to my comparison. In the following, with the help of the NbClust package the optimal cluster number was determined for the K-means cluster procedure. As it can be seen in

23 https://www.artec3d.com/files/pdf/Space-Spider-Booklet-EURO.pdf

24 I would like to note that laying out the painted image is only available in the case of those vases which have a cylindrical painted surface that does not have a horizontal break. This means that while the method does not work with amphorae for example, it is perfectly fine for lekythoi.

It is far from me to understate the importance of hand drawing, which is indispensable when it comes to observing the details of an image. But it is a fact that despite all efforts (if the vase shape permits), a scanned and laid-out image is much more accurate than a hand-drawn one.

25 I have scanned 16 restored or fragmented pieces, however I have excluded these from the comparison, as when it comes to analysing full profiles, these items could have negatively affected the results.

26 https://www.r-project.org. I have used version 3.4.3.

27 BonHOMme et al. 2014. 
Figure 1. I realized that the optimal cluster number should be either four or six. The program package has made a lot of statistical analyses, ${ }^{28}$ which supported the six cluster groups more, so I choose that cluster number.
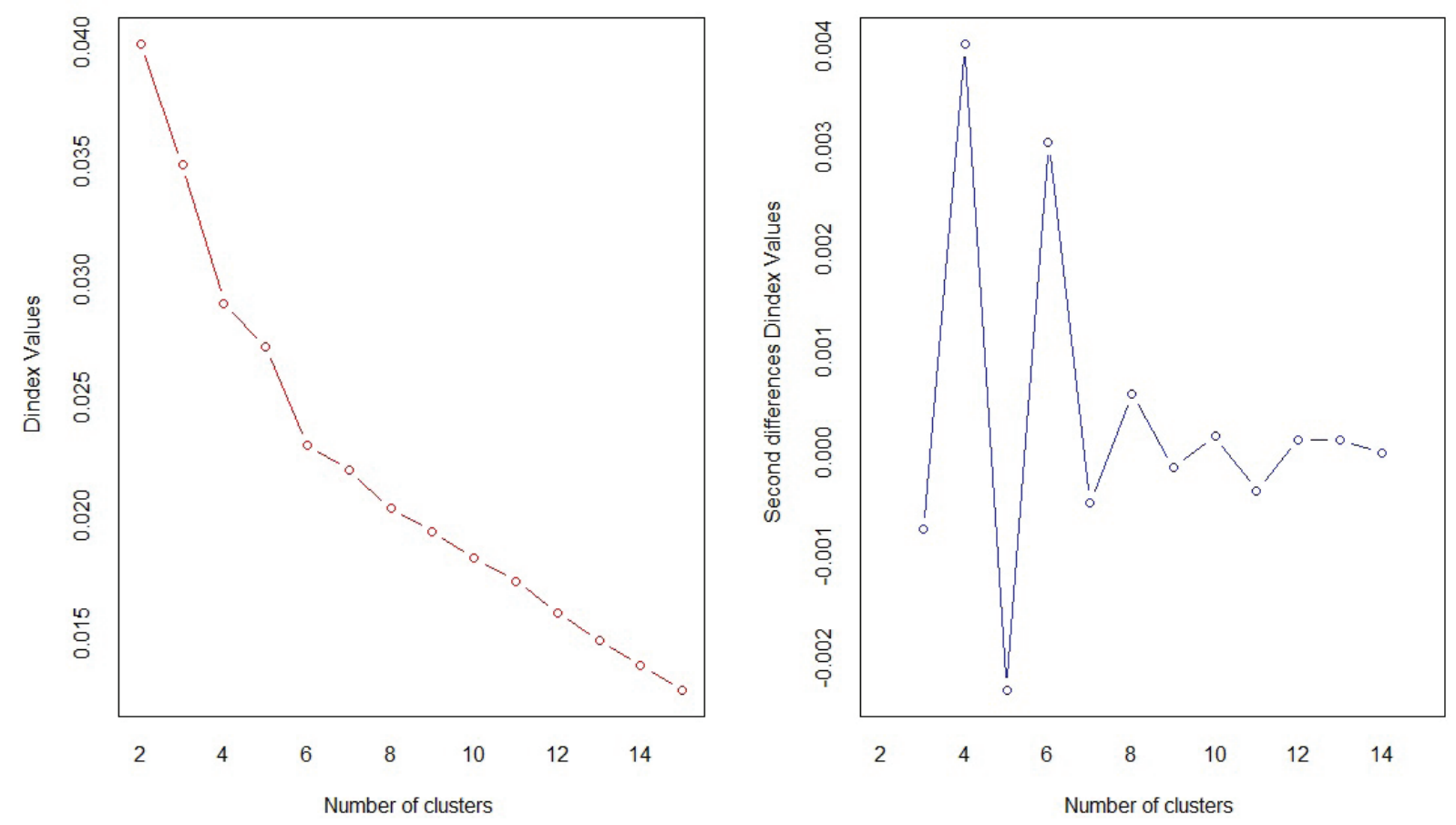

Fig. 1. Agglomeration schedule coefficients (imported from $R$, calculated by NbClust package).

The K-means cluster procedure requires a lot of calculation. The characteristic of the algorithm is that it finds the best cluster proportion from a randomly selected case. Because of this I ran the program 100.000 times, with six cluster groups ${ }^{29}$ and I choose those grouping, which maximized the distance between each cluster group. The result of this analysis can be seen on Figure 2. Each cluster group is signed by no. 1 to 6 and the number of vases in each cluster group in a row is the following: 10, 3, 8, 5, 2, and 2. On Figure 3 the sum squared distance of the clusters can be seen.

Examining Figure 2 we can conclude that the lekythoi types are located in six clusters, which correspond to the terminology of classical archaeology. Cluster 1 consists of ordinary cylinder-shaped lekythoi, and while those of Cluster 2 are also cylindrical in shape, their mouth and neck areas are larger in proportion than those of the former group. On the other hand, vases of Cluster 3, despite being cylindrical as well, have proportionately smaller mouths and necks than the ones in Cluster 1. Cluster 4 contains broad-shouldered cylindrical shapes, while the archaizing shoulder-lekythoi belong in Clusters 5 and 6, which are divided most probably by the broadness of the vases' shoulders.

The whole picture becomes much more intriguing when we look at the data in Figure 8 in reference to the results in which the relevant clusters are listed in the Cluster outline column. The difference between Clusters 1, 2, and 3 is clearly visible there: among the members of Cluster 2 are two very late, small black-figure lekythoi with white ground, where the smaller size goes along with the relatively larger mouth, moreover there is a red-figure one, in which

28 The detailed deduction of these, with illustrations, could not be obtained from NbClust, only the results.

29 This is part of $R^{\prime}$ s basic package. 
case it seems likely that this shape variation was more popular. It is an important observation that all vases of Cluster 1 belong to the workshops of the Haimon and the Beldam Painter with no exception. ${ }^{30}$ All pieces of Cluster 3 can be dated to the first quarter of the $5^{\text {th }}$ century $\mathrm{BC}$, while those in Cluster 4 were made around the turn of the century, probably a little earlier, just as the archaizing lekythoi of Clusters 5 and 6 - which shows us the trends in the changing shapes of the lekythoi. Clusters 1 and 2 seem to be extremely close to each other: the pattern-lekythoi of Cluster 2 seem to be linked to the Beldam or the Haimon Workshop. Between these two distinctive groups, Cluster 3 seems to represent the transition: its pieces show connections to both directions.

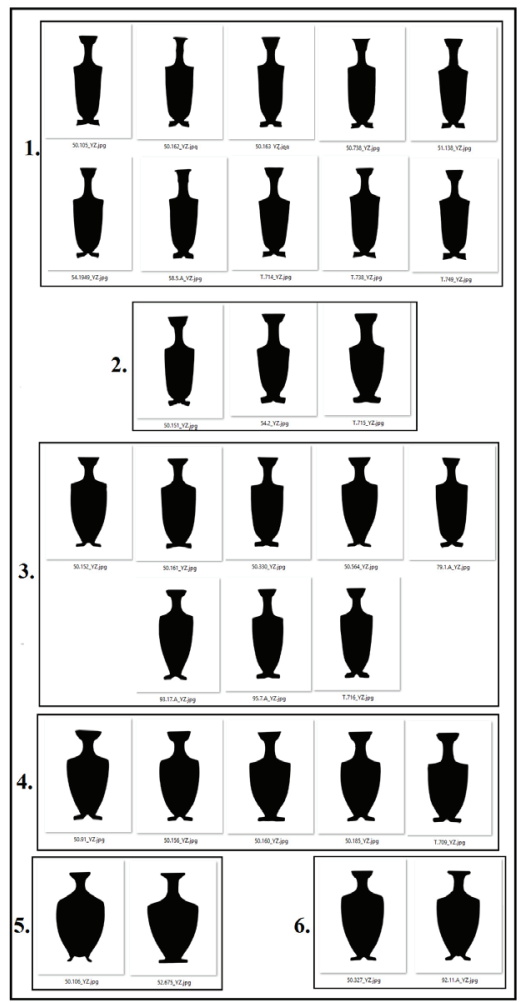

$a$

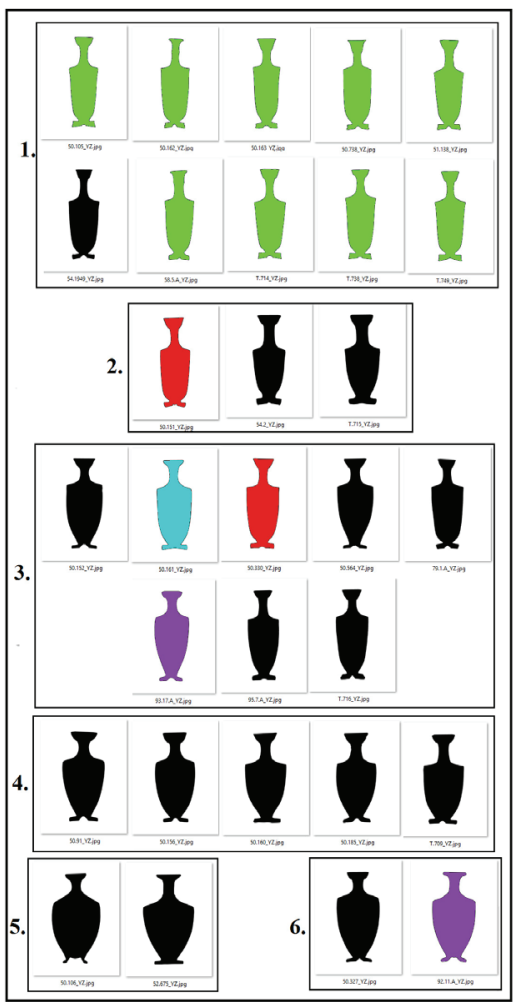

$b$

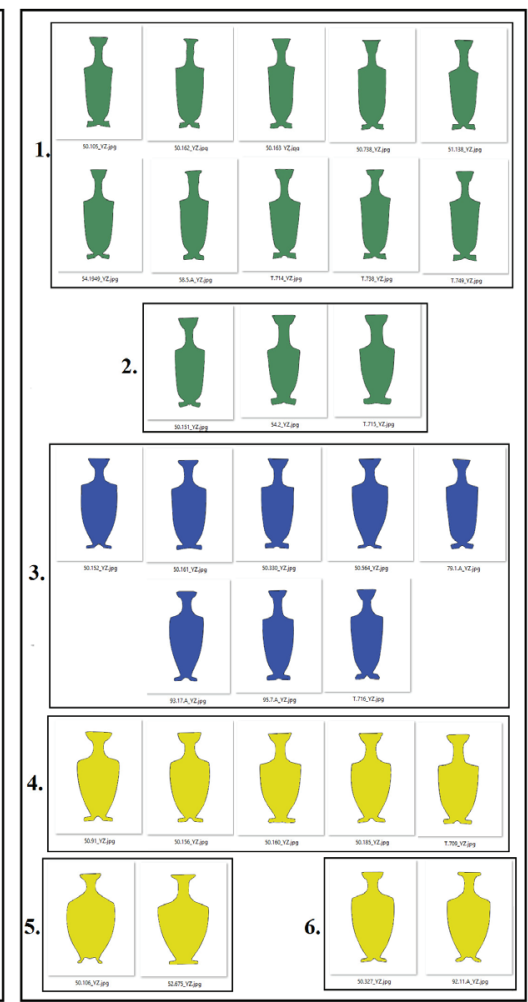

$c$

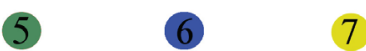

Fig. 2. The result of K-means clustering analysis in case of outline analysis. a - The 6 clusters, $\mathrm{b}-$ The six clusters with painters, workshops, groups and styles: 1 - Haimon-Beldam Workshop, 2 - Gela Painter, 3 - Cock Group, 4 - Red-figure lekythoi. c - The six clusters with dating: 5 - 490-450 BC, 6 - 500-475 BC, $7-510-490$ BC.

\section{Full Profile Examination - Landmark Configuration}

After carrying out the outline analysis, I have decided to test landmark configuration on the objects. For this I have exported the model in obj format, then, using the software Geomagic Design $X$, I have sectioned the image in the middle with the $y z$ plane excluding the ear. This was necessary since the potter's intention while shaping up the rim is best visible in this area. In the cases where there was a breakage on the surface of the vase, I have chosen a plane containing the vertical centreline to section the image. 
A New Method in Attribution? Attempts of the Employment of Geometric Morphometrics...

\begin{tabular}{|c|c|c|c|c|c|c|c|c|}
\hline \multirow{2}{*}{$\begin{array}{c}\text { Distance } \\
\text { between the } \\
\text { Clusters }\end{array}$} & \multicolumn{9}{|c|}{ Distance between the pieces inside the clustres } & $\begin{array}{c}\text { Distance between } \\
\text { cach piece } \\
\text { without the } \\
\text { cluster procedure }\end{array}$ & $\begin{array}{c}\text { Reliability of the } \\
\text { clustering }\end{array}$ \\
\cline { 2 - 9 } & 1 & 2 & 3 & 4 & 5 & 6 & 0.13576 & $87.24 \%$ \\
\hline 0.11844 & 0.00501 & 0.00161 & 0.00524 & 0.00266 & 0.11210 & 0.00070 & \\
\hline
\end{tabular}

Fig. 3. The reliability of the cluster analysis in case of outline analysis.

Then, I have taken 15 landmarks on one side of the vase on the section created by the plane: five landmarks on the mouth area (one at the rim, one on the top at the possible fold recurvery, one in the middle, one at the start of the lower arc, and one at the point where the mouth meets the neck), one landmark on the joint at the bottom of the neck, five landmarks on the body (one at the shoulder, one below it, one at the middle, one at the start of the lower arc, and one at the point where it connects to the foot), as well as four landmarks on the side of the foot (one at the top, one at the bottom, two in the middle - or in the case of a stepped foot, one at every break-point) (Fig. 4). I would like to note that to conduct a landmark configuration, an immense amount of tables were needed, which I have enclosed in a separate Appendix.

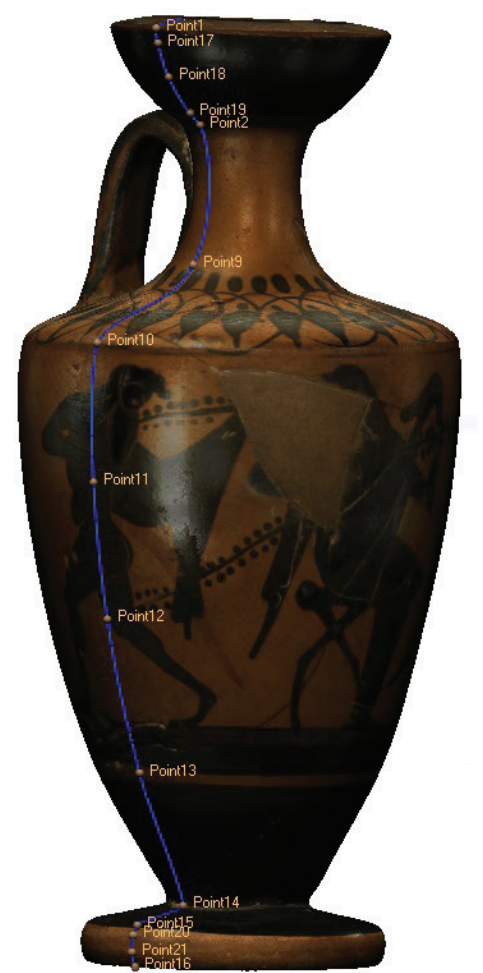

50.91

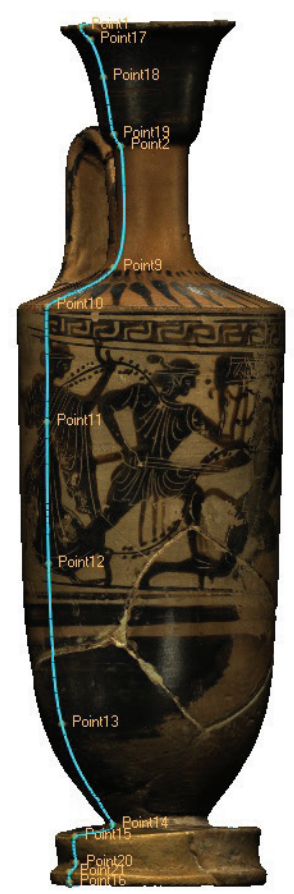

50.738

Fig. 4. Location of landmarks on lekythoi.

I have exported the recorded points to csv format and imported it into $R$. I ran Generalized Procruste Analysis (GPA), which scaled, rotated, and offseted them to minimize the distance between different landmark sets for comparison, therefore making the data set scale, offset and rotation independent. Since I scored points along one axis in Geomagic Design X, one of the $x, y$, and $z$ coordinates determining the points was constant. For this reason, after completing the GPA, and leaving the $z$ coordinate we have got a 2D set of data, with $x$ and $y$ coordinates. This includes for each vase 30 variables for 15 points. 
First, as a preliminary analysis of the clustering procedure, I performed the factor analysis (PCA) on the data with which I tried to reduce the number of variables. In the absence of the fulfilment of the requirements, I did not analyse with the classic method. There are several reasons why the requirements have not been met: the size of the sample set or the method of data extraction(as I tried to reconstruct the same outline as by the outline analysis, using only 15 landmark points where the correlation was too small). This was automatically detected by $R$ and the corr.smooth function brought the data closer to each other so that it could complete the PCA. The communality table clearly shows that the factors keep the data even after factorization, since the smallest V15 variable also has a 0.81 communality value, so it retains the value of the variable in $81 \%$ (Appendix 1). Factor analysis suggested 5 factors, in which the $86 \%$ of the data remained (Appendix 2).

The data in Appendix 3 show the proportion of each variable roleplay in each factor. The absolute values of these ratios should be greater than 0.7 in at least one component. If they are smaller, they do not affect the actual factor. Our factor analysis is correct if all variables reach a minimum 0.7 value, but as we can see, this has not occurred in many places. Since there was a factor that was not influenced by any of the variables and there were many variables that did not fit into one of the factors, I tried varimax rotation, which increased the variance between the variables. This way, $86 \%$ of the data remained in the five factors (Appendix 4).

After the rotation, the situation has improved, as every factor was influenced well by variables, but there were still many variables that did not fit into any factors, as shown in Appendix 5.

To make my factor analysis correct and to do the cluster analysis, I could make two alterations: either exclude the least influential variable, or try less factors. Since I wanted to keep as many variables as possible as I tried to describe the characteristics of the vases with a few points, I tried to reduce the numer of factors first. According to the pareto rule, it is important that factors should be determined in a way that they contain at least $80 \%$ of the data, so the factor number can only be reduced to 4 . In this case, this number equals to $81.6 \%$ without rotation (Appendix 2). The result can be seen in Appendix 6, where it is clear that after the reduction of the number of factors, many variables did not participate in any factor. So I decided to apply varimax rotation again. Since this calculation works with a given number of factors, the relative variance of the factors has differed from Appendix 4: 81.6\% of the data remained in the 4 factors (Appendix 7), just as before the rotation, only with a change in the proportions.

After rotation, the situation did not improve with four factor numbers either (Appendix 8). Although all factors were influenced by a variable, many variables did not fit into any of the factors.

Because of my results, I was forced to leave the variable with the lowest influence indicator, which is based on Appendices 3, 5 and 6. Since all variables are one half of a point coordinate $(x ; y)$, if I remove one, I have to remove its pair too, which is V11 for V26. After removing them, I restarted the PCA with the corr.smooth function, which again recommended 5 factors with $88 \%$ data retention, but even found 4 factors acceptable, where this figure was 83.5\% (Appendix 9).

Appendix 10 shows that the situation has not improved yet, 11 variables did not fit into any of the factors, and the last 3 factors were not influenced by any variable. 
Because of this, varimax rotation was performed again, after which 5 factors were sufficient for the applicable data retention by $88 \%$ (Appendix 11).

After the rotation, the situation was the same as before: all factors were influenced by some variables, but still many variables did not fit into any of the factors, so my factor analysis was not yet correct (Appendix 12).

In the following, I tried to classify the data in 4 factors without varimax rotation, but it did not help (Appendix 13), therefore I used rotation. Then, just like before the rotation (Appendix 9), 83.5\% of the data remained in the 4 factors (Appendix 14). The results are shown in Appendix 15.

Since we did not get the correct factor analysis, we had to leave another two variables, which became the least influential: V21 and its pair, V6.

After running PCA again, the $R$ did not use the corr.smooth, as the requirements of the analysis have been met. After the change, the suggested number of factors was still 5 or 4 . I checked with both number of factors, with varimax rotation and without, but there were always variables that did not fit into any factor, so I had to exclude new variables, V15 and V30, but it always failed. Variables V25 and V10, V18 and V3, V17 and V2, V1 and V16, and V8 and V23 have been abandoned before I got the right factor analysis. I confirm my steps in the 'Appendices' section with tables. However, I excluded 16 (8 points) out of 30 variables (15 points), which is $53.3 \%$ of the original data, so we can say that unfortunately our data set cannot be interpreted statistically Figure 5 illustrates which points remained after the variables were excluded and what kind of comparison resulted from that.
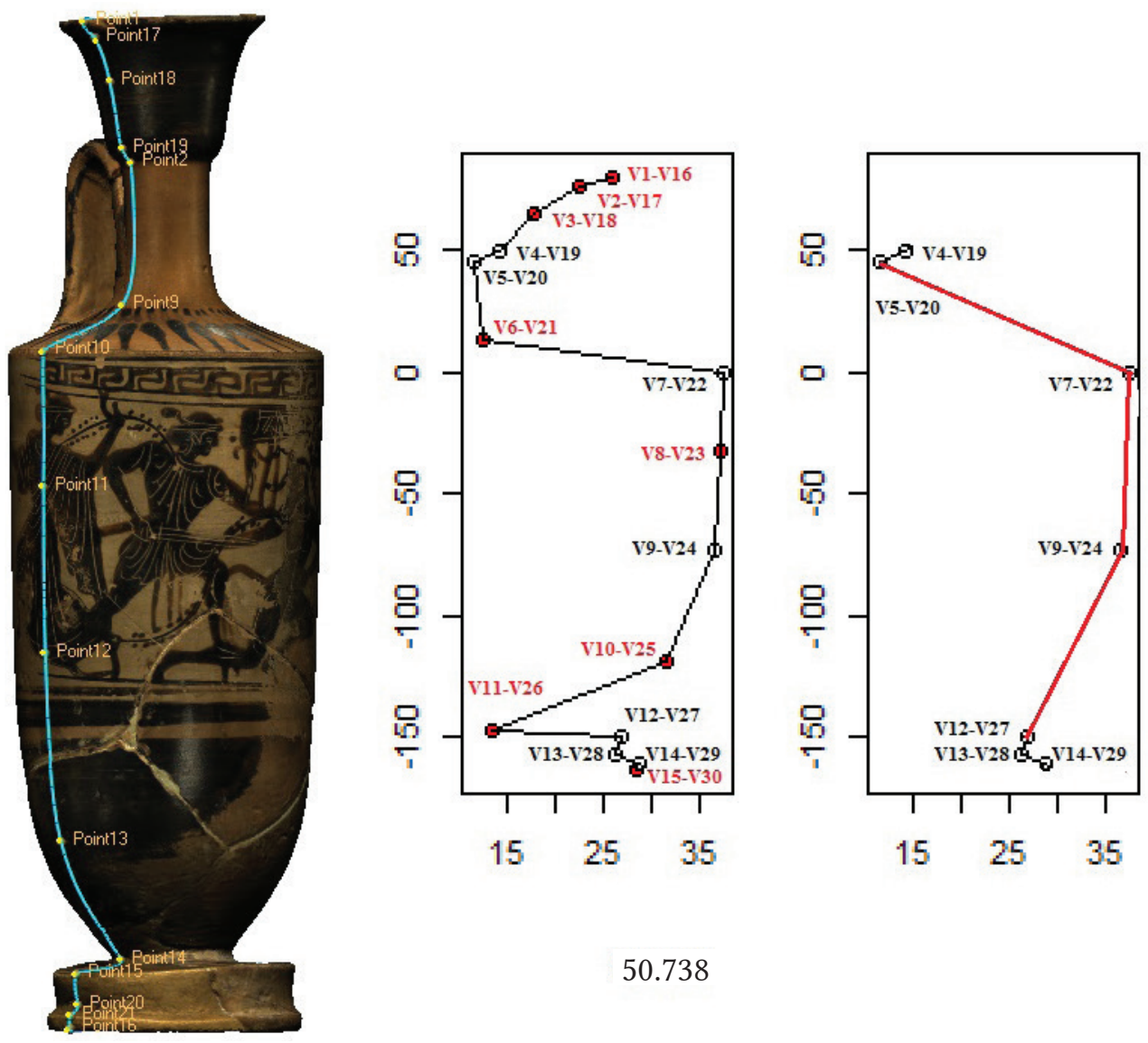

50.738

Fig. 5. Remained landmarks after the variables were left out and the basement of the comparison. 
Regardless, it was then possible to run a cluster analysis in $R$ to see if the results were relevant from an archaeological point of view or not. The PCA provided relative variations for 14 remaining variables along 14 axes. The first four axes represent $90 \%$ of the variance of the total data set, so these four can be considered significant and relevant to my comparison (Appendix 60).

After the varimax rotation, all variables were applied to all factors, so my factor analysis could be seen as performed (Appendix 61), although still not statistically correct.Then, with the help of the NbClust package, I determined the optimal number of groups for the K-means clustering procedure, which was six (Figure 6). Thus, I ran the K-means clustering process for 6 clusters, which result can be seen on Figure $7 .{ }^{31}$ Similarly to the methodology applied in the outline analysis period, the algorithm was runned 100,000 times and chose the division that maximizes the distance between the clusters. Each cluster group is signed by number 1 to 6 and the number of vases in each cluster group in a row is the following: 2, 3, 4, 6, 7, and 7 . Appendix 62 shows the sum squared distance between the individuals and the clusters.
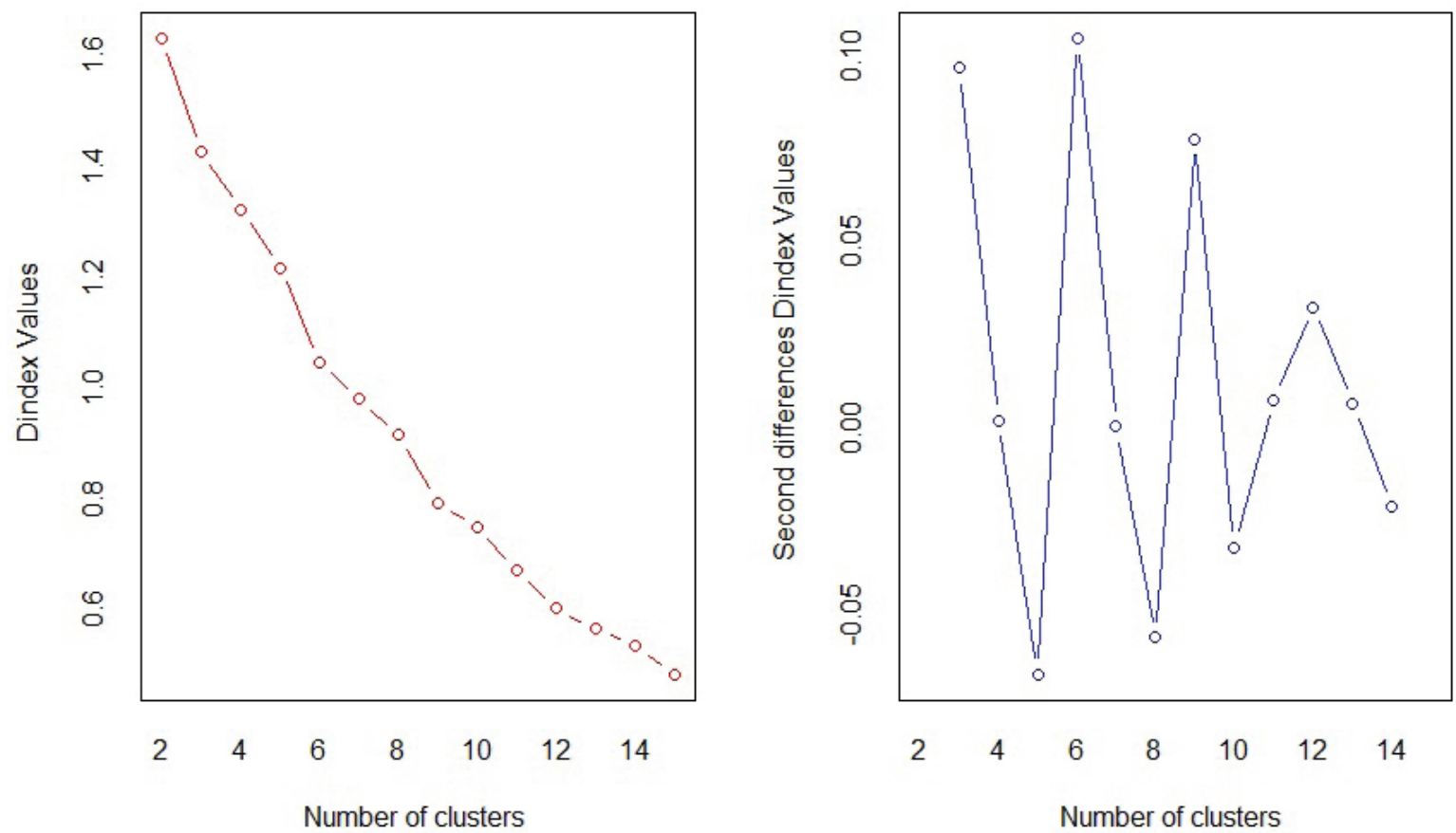

Fig. 6. Agglomeration schedule coefficients (imported from $R$, calculated by $\mathrm{NbClust}$ package).

Looking at Figure 7 and Figure 8 (Cluster landmark column) alongside, we can conclude that even though several landmarks were excluded, the classification turned out to be rather useful. Cluster 1 consists of the two smallest lekythoi of the assemblage, which is understandable considering the divergence in their proportions in comparison to the taller vases. Cluster 2 is also based on some characteristic differences: the lekythoi of this group are of the archaizing form with short mouth and neck areas and broad, spherical bodies. Interestingly, all of them are dated to the turn of the $6^{\text {th }}$ and $5^{\text {th }}$ centuries BC, possibly a little earlier, and they cover Clusters 5 and 6 of the outline analysis. Cluster 3 is also significant, since only pieces connected to the Beldam or Haimon Workshops belong in it - although not all of them. The other vases from Cluster 1 of the outline analysis seem to have split between Clusters 4 and 5. The lekythoi in Cluster 4 are cylinder-shaped with longer necks, while 


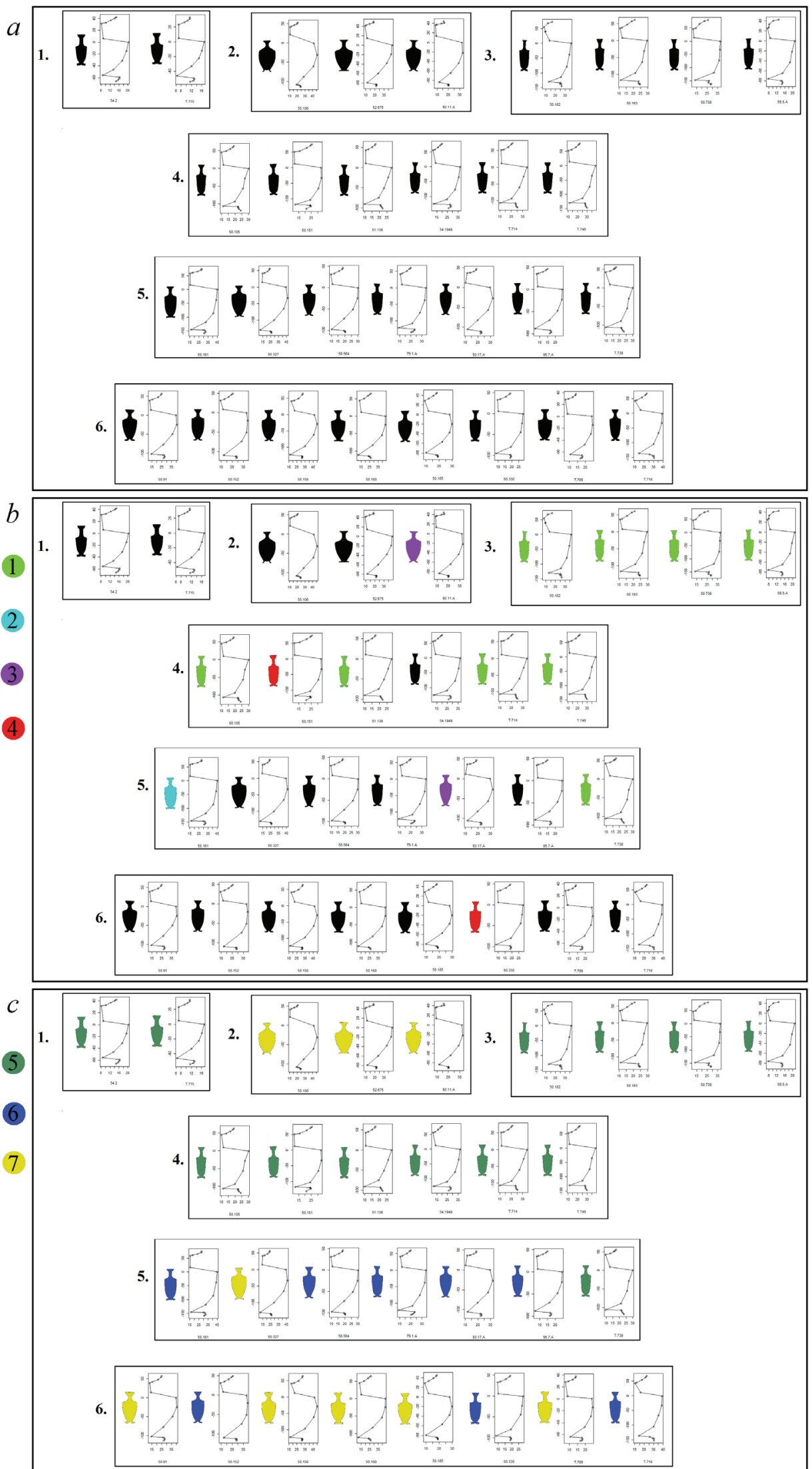

Fig. 7. The result of K-means clustering in case of landmark configuration. a - The six clusters, $\mathrm{b}-$ The six clusters with painters, workshops, groups and styles: 1 - Haimon-Beldam Workshop, 2 - Gela Painter, 3 - Cock Group, 4 - Red-figure lekythoi. c. - The six clusters with dating: 5 - 490-450 BC, 6 - 500-475 BC, 7 - 510-490 BC. 
Szilvia JoHÁczi

\begin{tabular}{|c|c|c|c|c|c|c|c|c|c|c|c|c|c|}
\hline $\begin{array}{l}\text { Fig. } \\
\text { No. }\end{array}$ & $\begin{array}{l}\text { Itinerary } \\
\text { Number }\end{array}$ & $\begin{array}{l}\text { Date } \\
(B C)\end{array}$ & $\begin{array}{c}\text { Attributed to } \\
(\text { by })\end{array}$ & Style & Shape type & $\begin{array}{l}\text { Cluster } \\
\text { outline }\end{array}$ & $\begin{array}{c}\text { Cluster } \\
\text { landmark }\end{array}$ & $\begin{array}{l}\text { High } \\
(\mathrm{cm})\end{array}$ & Foot & Mouth & Shoulder & $\begin{array}{l}\text { Bottom of } \\
\text { the body }\end{array}$ & $\begin{array}{l}\text { Top of the } \\
\text { body }\end{array}$ \\
\hline $1 / 1$ & 50.105 & $470-450$ & $\begin{array}{c}\text { Beldam Painter } \\
\text { (J. D. Beazley) }\end{array}$ & $\begin{array}{l}\text { white- } \\
\text { ground }\end{array}$ & cylinder & 1 & 4 & 17.9 & trochilus & cup & horizontal & round & $\begin{array}{l}\text { swings in a } \\
\text { sharp angle }\end{array}$ \\
\hline $1 / 2$ & 50.106 & $500 \mathrm{c}$. & & $\begin{array}{l}\text { black- } \\
\text { figure }\end{array}$ & archaizing & 5 & 2 & 17 & echinus & cup & steep & narrow & $\begin{array}{l}\text { swells out } \\
\text { slightly }\end{array}$ \\
\hline $1 / 3$ & 50.151 & $480-470$ & $\begin{array}{l}\text { Rhodos } 11966 \\
\text { Group } \\
\text { (J. D. Beazley) }\end{array}$ & red-figure & cylinder & 2 & 4 & 20.7 & discos & calyx & steep & round & straight \\
\hline $1 / 4$ & 50.152 & $500-490$ & & $\begin{array}{l}\text { black- } \\
\text { figure }\end{array}$ & $\begin{array}{l}\text { cylinder (broad- } \\
\text { shouldered) }\end{array}$ & 3 & 6 & 16 & torus & cup & horizontal & narrow & straight \\
\hline $1 / 5$ & 50.156 & $510-500$ & & $\begin{array}{l}\text { black- } \\
\text { figure }\end{array}$ & $\begin{array}{l}\text { cylinder (broad- } \\
\text { shouldered) }\end{array}$ & 4 & 6 & 19.5 & torus & cup & curved & narrow & $\begin{array}{l}\text { swells out } \\
\text { slightly }\end{array}$ \\
\hline $1 / 6$ & 50.160 & $510 \mathrm{c}$. & & $\begin{array}{l}\text { black- } \\
\text { figure }\end{array}$ & $\begin{array}{l}\text { cylinder (broad- } \\
\text { shouldered) }\end{array}$ & 4 & 6 & 18.5 & trochilus & cup & horizontal & narrow & straight \\
\hline $1 / 7$ & 50.161 & $490 \mathrm{c}$. & $\begin{array}{c}\text { Gela Painter } \\
\text { (J. Gy. Szilágyi) }\end{array}$ & $\begin{array}{l}\text { white- } \\
\text { ground }\end{array}$ & $\begin{array}{l}\text { cylinder (broad- } \\
\text { shouldered) }\end{array}$ & 3 & 5 & 23.4 & trochilus & echinus & steep & narrow & straight \\
\hline $1 / 8$ & 50.162 & $480-470$ & $\begin{array}{c}\text { Haimon or } \\
\text { Beldam } \\
\text { Workshop } \\
\text { (J. Gy. Szilágyi) }\end{array}$ & $\begin{array}{l}\text { black- } \\
\text { figure }\end{array}$ & cylinder & 1 & 3 & 22 & $\begin{array}{l}\text { two } \\
\text { degrees }\end{array}$ & chimney & horizontal & round & $\begin{array}{l}\text { swings in a } \\
\text { sharp angle }\end{array}$ \\
\hline $1 / 9$ & 50.163 & $480 \mathrm{c}$. & $\begin{array}{c}\text { Haimon } \\
\text { Workshop } \\
\text { (J. Gy. Szilágyi) }\end{array}$ & $\begin{array}{l}\text { black- } \\
\text { figure }\end{array}$ & cylinder & 1 & 3 & 19.2 & $\begin{array}{l}\text { two } \\
\text { degrees }\end{array}$ & calyx & horizontal & narrow & $\begin{array}{l}\text { swings in a } \\
\text { sharp angle }\end{array}$ \\
\hline $1 / 10$ & 50.185 & $490-480$ & & $\begin{array}{l}\text { black- } \\
\text { figure }\end{array}$ & $\begin{array}{l}\text { cylinder (broad- } \\
\text { shouldered) }\end{array}$ & 4 & 6 & 13 & torus & cup & horizontal & narrow & $\begin{array}{l}\text { swells out } \\
\text { slightly }\end{array}$ \\
\hline $1 / 11$ & 50.327 & $500 \mathrm{c}$. & & $\begin{array}{l}\text { black- } \\
\text { figure }\end{array}$ & $\begin{array}{l}\text { cylinder (broad- } \\
\text { shouldered) }\end{array}$ & 6 & 5 & 19 & torus & cup & curved & narrow & $\begin{array}{l}\text { swells out } \\
\text { slightly }\end{array}$ \\
\hline $1 / 12$ & 50.330 & $480 \mathrm{c}$. & $\begin{array}{c}\text { Brygos } \\
\text { (J. Gy. Szilágyi) }\end{array}$ & red-figure & $\begin{array}{l}\text { cylinder (broad- } \\
\text { shouldered) }\end{array}$ & 3 & 6 & 15.6 & torus & calyx & horizontal & round & straight \\
\hline $1 / 13$ & 50.564 & $480 \mathrm{c}$. & & $\begin{array}{l}\text { black- } \\
\text { figure }\end{array}$ & $\begin{array}{l}\text { cylinder (broad- } \\
\text { shouldered) }\end{array}$ & 3 & 5 & 15.5 & trochilus & cup & horizontal & narrow & straight \\
\hline $1 / 14$ & 50.738 & $480 \mathrm{c}$. & $\begin{array}{l}\text { Pholos Group } \\
\text { (J. Gy. Szilágyi) }\end{array}$ & $\begin{array}{l}\text { white- } \\
\text { ground }\end{array}$ & cylinder & 1 & 3 & 24.5 & $\begin{array}{c}\text { two } \\
\text { degrees }\end{array}$ & calyx & steep & round & straight \\
\hline $1 / 15$ & 50.91 & $500 \mathrm{c}$. & & $\begin{array}{l}\text { black- } \\
\text { figure }\end{array}$ & $\begin{array}{l}\text { cylinder (broad- } \\
\text { shouldered) }\end{array}$ & 4 & 6 & 17 & torus & echinus & curved & narrow & $\begin{array}{l}\text { swells out } \\
\text { slightly }\end{array}$ \\
\hline $1 / 16$ & 51.138 & $470-450$ & $\begin{array}{c}\text { Beldam } \\
\text { Workshop } \\
\text { (J. Gy. Szilágyi) }\end{array}$ & $\begin{array}{l}\text { black- } \\
\text { figure }\end{array}$ & cylinder & 1 & 4 & 16.1 & torus & cup & steep & narrow & $\begin{array}{l}\text { swings in a } \\
\text { sharp angle }\end{array}$ \\
\hline $1 / 17$ & 52.675 & $510-500$ & & $\begin{array}{l}\text { black- } \\
\text { figure }\end{array}$ & $\begin{array}{l}\text { cylinder (broad- } \\
\text { shouldered) }\end{array}$ & 5 & 2 & 13 & torus & echinus & curved & narrow & straight \\
\hline $1 / 18$ & 54.1949 & $450 \mathrm{c}$. & & $\begin{array}{l}\text { white- } \\
\text { ground }\end{array}$ & cylinder & 1 & 4 & 21.8 & torus & calyx & horizontal & round & $\begin{array}{l}\text { swings in a } \\
\text { sharp angle }\end{array}$ \\
\hline $1 / 19$ & 54.2 & $500-450$ & & $\begin{array}{l}\text { white- } \\
\text { ground }\end{array}$ & cylinder & 2 & 1 & 10.92 & discos & cup & horizontal & narrow & $\begin{array}{l}\text { swings in a } \\
\text { sharp angle }\end{array}$ \\
\hline $1 / 20$ & 58.5.A & $500 \mathrm{c}$. & $\begin{array}{l}\text { Beldam Painter } \\
\text { (Sz. Joháczi) }\end{array}$ & $\begin{array}{l}\text { black- } \\
\text { figure }\end{array}$ & cylinder & 1 & 3 & 13.22 & discos & chimney & horizontal & round & $\begin{array}{l}\text { swings in a } \\
\text { sharp angle }\end{array}$ \\
\hline $1 / 21$ & 79.1.A & $500-475$ & & $\begin{array}{l}\text { black- } \\
\text { figure }\end{array}$ & cylinder & 3 & 5 & 19.43 & discos & cup & horizontal & round & straight \\
\hline $1 / 22$ & 92.11.A & $510-500$ & $\begin{array}{l}\text { Cock Group } \\
\text { (J. Gy. Szilágyi) }\end{array}$ & $\begin{array}{l}\text { black- } \\
\text { figure }\end{array}$ & archaizing & 6 & 2 & 13.51 & echinus & echinus & steep & narrow & $\begin{array}{l}\text { swells out } \\
\text { slightly }\end{array}$ \\
\hline $1 / 23$ & 93.17.A & $500-480$ & $\begin{array}{l}\text { Cock Group } \\
\text { (J. Gy. Szilágyi) }\end{array}$ & $\begin{array}{l}\text { black- } \\
\text { figure }\end{array}$ & $\begin{array}{l}\text { cylinder (broad- } \\
\text { shouldered) }\end{array}$ & 3 & 5 & 16.5 & torus & cup & steep & narrow & $\begin{array}{l}\text { swells out } \\
\text { slightly }\end{array}$ \\
\hline $1 / 24$ & 95.7.A & $475-450$ & & $\begin{array}{l}\text { black- } \\
\text { figure }\end{array}$ & cylinder & 3 & 5 & 14.75 & torus & cup & horizontal & narrow & straight \\
\hline $1 / 25$ & T.709 & $500-480$ & & $\begin{array}{l}\text { black- } \\
\text { figure }\end{array}$ & $\begin{array}{l}\text { cylinder (broad- } \\
\text { shouldered) }\end{array}$ & 4 & 6 & 11 & torus & cup & horizontal & narrow & straight \\
\hline $1 / 26$ & Т.714 & $470-450$ & $\begin{array}{c}\text { Beldam } \\
\text { Workshop } \\
\text { (J. Gy. Szilágyi) }\end{array}$ & $\begin{array}{l}\text { white- } \\
\text { ground }\end{array}$ & cylinder & 1 & 4 & 19.1 & trochilus & cup & horizontal & round & $\begin{array}{l}\text { swings in a } \\
\text { sharp angle }\end{array}$ \\
\hline $1 / 27$ & T.715 & $500-450$ & & $\begin{array}{l}\text { white- } \\
\text { ground }\end{array}$ & cylinder & 2 & 1 & 9.85 & torus & cup & horizontal & narrow & straight \\
\hline $1 / 28$ & T.716 & $500-475$ & & $\begin{array}{l}\text { white- } \\
\text { ground }\end{array}$ & cylinder & 3 & 6 & 22.4 & $\begin{array}{l}\text { two } \\
\text { degrees }\end{array}$ & cup & steep & narrow & straight \\
\hline $1 / 29$ & T.738 & $470-450$ & $\begin{array}{c}\text { Beldam } \\
\text { Workshop } \\
\text { (J. Gy. Szilágyi) }\end{array}$ & $\begin{array}{l}\text { white- } \\
\text { ground }\end{array}$ & cylinder & 1 & 5 & 17.2 & trochilus & cup & steep & round & $\begin{array}{l}\text { swings in a } \\
\text { sharp angle }\end{array}$ \\
\hline $4 / 5$ & T.749 & $470-450$ & $\begin{array}{c}\text { Beldam } \\
\text { Workshop } \\
\text { (J. Gy. Szilágyi) }\end{array}$ & $\begin{array}{l}\text { black- } \\
\text { figure }\end{array}$ & cylinder & 1 & 4 & 22.5 & trochilus & cup & steep & round & $\begin{array}{l}\text { swings in a } \\
\text { sharp angle }\end{array}$ \\
\hline
\end{tabular}

Fig. 8. Summary table. 
those in Cluster 5 are of stouter, shorter necks, in proportion to the taller body. It is slightly puzzling to see the piece under inv. no. 50.327 turn out to be in Cluster 5, since manually I would classify it along with the archaizing vases of group no. 1, as can be seen in the results of the outline analysis. Cluster 6 contains the broad-shouldered, steeply narrowing cylinder-shape lekythoi, although some anomalies can be seen here as well: the cylindrical pieces of inv. no. 50.330 and T.716. As can be seen in Figure 5, the basis for the comparison is most probably the breadth of the body, the joint height of the shoulder and neck areas, and quite possibly also the differentiated shape of the foot.

It can be stated in conclusion that the outline analysis provides a cloud of data that is statistically interpretable and well examinable. This method is certainly better suited to analyse the vases with geometric morphometrics than landmark configuration. In the case of the latter, data collection is a quite delicate step: as our objects are handmade, we do not have a large number of significant, similar landmarks which should be the same on each and every vase, providing certain, well comparable data. The number of vases involved in the analysis in the case of this method is more significant, as results are fewer and more sensitive here.

Based on these observations it seems that the first results of geometric morphometrics using a $3 \mathrm{D}$ reconstruction technique are quite promising, as the method was able to divide the assemblage into groups that could be interpreted in of archaeology, as well as, in some cases, classify the works of certain painters into one cluster. On account of this, I believe that broadening this research by including other vase forms in an analysis similar to that described above would be useful . I would also suggest the developing of a general practical methodology, as the use of morphometrics in archaeological research, especially concerning pottery as well as in the field of Classical archaeology is still in its infancy. ${ }^{32}$ It would be indispensable to find the exact technical detail(s) in the case of each vase form with the comparison of which we could shed light on the characteristics of certain workshops. In the case of lekythoi this could mean the joining of the neck (the absence or existence and nature of the 'drip-ring'), which is different in each and every shape.*

\section{References}

Beazley, J. D. 1956: Attic Black-Figure Vase Painters. Oxford.

Bonhomme, V. - Pico, S. - Gaucherel, C. - Claude, J. 2014: Momocs: Outline Analysis Using R. Journal of Statistical Software 56, 1-24.

von Bothmer, D. 1985: Beazley the teacher. In: Kurtz, D. C. (ed.): Beazley and Oxford. Oxford University Committee for Archaeology 10, 5-17.

Elewa, A. M. T. (ed.) 2010: Morphometrics to Nonmorphometricians. Springer.

Haspels, C. H. E. 1936: Attic Black-Figured Lekythoi. Paris.

Jubier-Galinier, C. 2003: L'atelier à figures noires tardives des Peintres de Diosphos et de Haimon. In: Rouillard, P. - Verbanck-Piérard, A. (eds.): Le vase grec et ses destins. München, 79-89.

Jubier-Galinier, C. 2016: Les attributi ons des vases à figures noires tardives en question. In: Esснвасн, N. - SснміDт, S. (eds.): Töpfer Maler Werkstatt. Zuschreibungen in der griechischen Vasenmalerei und die Organisation antiker Keramikproduktion. München, 130-138.

32 Some works to start with: ELEWA 2010; SELDEN et al. 2014.

* I would like to express my gratitude for the immense help of Attila Joháczi, Borbála Mohácsi and Máté Pinczel. 
Kurtz, D. C. 1975: Athenian White Lekythoi. Patterns and Painters. Oxford.

Morgan, C. 2004: Attic Fine Pottery of the Archaic to Hellenistic Periods in Phanagoria. Phanagoria Studies 1. Leiden.

Selden, R. Z. -Perttula, T. K. - O’Brien, M. J. 2014: Toward a Morphometric Phylogeny of Caddo Ceramics: A Test of 3D Geometric Morphometrics. Texas Academy of Science Annual Meeting. Galveston, Texas. (Poster)

Shefton, B. B. 1999: The Lancut Group. Silhouette technique and coral red. Some Attic $\mathrm{V}^{\text {th }}$ century export material in Pan-Mediterranean sight. In: Lissarrague, F. - Rouillard, P. - Rouveret, A. Villanueva Puig, M.-C. (eds.): Céramique et peinture grecques. Modes d'emploi. Paris, 463-475.

\section{Appendices}

\section{Appendix 1}

\begin{tabular}{|c|c|}
\hline Variables & Communalities \\
\hline V1 & 0.9713926 \\
\hline V2 & 0.9710840 \\
\hline V3 & 0.9251225 \\
\hline V4 & 0.9811602 \\
\hline V5 & 0.9063152 \\
\hline V6 & 0.9215820 \\
\hline V7 & 0.9448618 \\
\hline V8 & 0.9084362 \\
\hline V9 & 0.8453972 \\
\hline V10 & 0.8988113 \\
\hline V11 & 0.9390499 \\
\hline V12 & 0.9221864 \\
\hline V13 & 0.9384788 \\
\hline V14 & 0.8844893 \\
\hline V15 & 0.8061764 \\
\hline V16 & 0.9469621 \\
\hline V17 & 0.9680996 \\
\hline V18 & 0.9440753 \\
\hline V19 & 0.9093047 \\
\hline V20 & 0.9370658 \\
\hline V21 & 0.8638628 \\
\hline V22 & 0.9553005 \\
\hline V23 & 0.9754119 \\
\hline V24 & 0.9684783 \\
\hline V25 & 0.8225142 \\
\hline V26 & 0.9155669 \\
\hline V27 & 0.9153811 \\
\hline V28 & 0.9520261 \\
\hline V29 & 0.9305282 \\
\hline V30 & 0.8466942 \\
\hline & \\
\hline & \\
\hline
\end{tabular}


A New Method in Attribution? Attempts of the Employment of Geometric Morphometrics...

\section{Appendix 2}

Relative variance in case of 30 variables and 5 or 4 factors (PCA).

\begin{tabular}{|c|c|c|c|c|c|}
\hline & PC1 & PC2 & PC3 & PC4 & PC5 \\
\hline Relative variance & $41.10 \%$ & $19.80 \%$ & $12.40 \%$ & $8.20 \%$ & $4.40 \%$ \\
\hline E Relative variance & $41.10 \%$ & $60.90 \%$ & $73.40 \%$ & $81.60 \%$ & $86.00 \%$ \\
\hline
\end{tabular}

\section{Appendix 3}

Component matrix in case of 30 variables and 5 factors (PCA).

\begin{tabular}{|c|c|c|c|c|c|c|}
\hline \multirow{2}{*}{ Variables } & \multicolumn{5}{|c|}{ Components } & \multirow{2}{*}{$M A X$} \\
\hline & 1 & 2 & 3 & 4 & 5 & \\
\hline$V 1$ & 0.73656 & -0.12384 & -0.17537 & -0.61543 & -0.01054 & 0.73656 \\
\hline$V 2$ & 0.74294 & -0.12294 & -0.16891 & -0.61132 & -0.01740 & 0.74294 \\
\hline$V 3$ & 0.73297 & 0.32980 & 0.30919 & -0.31054 & -0.06422 & 0.73297 \\
\hline$V 4$ & 0.09203 & 0.63784 & 0.68199 & 0.21678 & -0.15072 & 0.68199 \\
\hline$V 5$ & 0.10852 & 0.68871 & 0.44956 & 0.45243 & -0.07267 & 0.68871 \\
\hline V6 & -0.67081 & 0.12028 & -0.47169 & 0.41290 & 0.21028 & 0.67081 \\
\hline$V 7$ & -0.29515 & -0.51033 & -0.62918 & 0.43357 & 0.08188 & 0.62918 \\
\hline$V 8$ & -0.46059 & -0.77533 & -0.15052 & 0.18512 & 0.13111 & 0.77533 \\
\hline$V 9$ & -0.54742 & -0.61421 & 0.34353 & -0.15222 & -0.08287 & 0.61421 \\
\hline$V 10$ & -0.61593 & -0.38759 & 0.47320 & -0.10198 & -0.33431 & 0.61593 \\
\hline$V 11$ & 0.78389 & 0.28852 & -0.03260 & -0.22682 & -0.23950 & 0.78389 \\
\hline$V 12$ & 0.81905 & 0.41935 & -0.18268 & -0.07668 & 0.14727 & 0.81905 \\
\hline$V 13$ & 0.63714 & 0.68758 & -0.06828 & -0.03819 & 0.18398 & 0.68758 \\
\hline$V 14$ & 0.37383 & 0.65029 & -0.36897 & -0.14700 & 0.35916 & 0.65029 \\
\hline$V 15$ & -0.22088 & 0.79835 & -0.17881 & 0.13555 & 0.22625 & 0.79835 \\
\hline$V 16$ & 0.40776 & -0.64995 & -0.07921 & -0.38199 & 0.40945 & 0.64995 \\
\hline V17 & 0.16373 & -0.44653 & 0.66170 & -0.03738 & 0.52393 & 0.66170 \\
\hline$V 18$ & 0.42960 & -0.36804 & 0.63031 & 0.33500 & 0.30271 & 0.63031 \\
\hline$V 19$ & 0.74609 & -0.32512 & -0.01780 & 0.29031 & -0.20295 & 0.74609 \\
\hline$V 20$ & 0.70750 & -0.17138 & -0.45629 & 0.35112 & -0.25909 & 0.70750 \\
\hline$V 21$ & 0.54679 & -0.34896 & -0.55852 & -0.01132 & -0.31369 & 0.55852 \\
\hline$V 22$ & -0.74699 & 0.52960 & -0.02647 & -0.18754 & -0.12575 & 0.74699 \\
\hline$V 23$ & -0.88689 & 0.40167 & 0.00008 & -0.12512 & 0.00696 & 0.88689 \\
\hline$V 24$ & -0.92393 & 0.25673 & 0.04012 & -0.20649 & 0.05314 & 0.92393 \\
\hline$V 25$ & -0.71467 & -0.23492 & -0.01792 & -0.33214 & 0.02577 & 0.71467 \\
\hline$V 26$ & 0.46798 & 0.22084 & -0.36937 & 0.20410 & 0.13160 & 0.46798 \\
\hline$V 27$ & 0.87138 & -0.10507 & 0.25299 & 0.07655 & -0.08436 & 0.87138 \\
\hline$V 28$ & 0.83320 & -0.10507 & 0.35787 & 0.16462 & -0.09163 & 0.83320 \\
\hline$V 29$ & 0.90362 & -0.20477 & 0.15373 & 0.19073 & 0.08208 & 0.90362 \\
\hline V30 & 0.65981 & -0.20661 & -0.06632 & 0.25485 & 0.07090 & 0.65981 \\
\hline \multicolumn{6}{|c|}{ Minimum value } & 0.46798 \\
\hline
\end{tabular}




\section{Appendix 4}

Relative variance with varimax rotation, in case of 30 variables and 5 factors (PCA).

\begin{tabular}{|c|c|c|c|c|c|}
\hline & $R C 1$ & $R C 2$ & $R C 3$ & $R C 4$ & $R C 5$ \\
\hline Relative variance & $29.80 \%$ & $18.30 \%$ & $16.50 \%$ & $13.40 \%$ & $0.80 \%$ \\
\hline E Relative variance & $29.80 \%$ & $48.10 \%$ & $64.60 \%$ & $78.00 \%$ & $86.00 \%$ \\
\hline
\end{tabular}

\section{Appendix 5}

Component matrix with varimax rotation, in case of 30 variables and 5 factors (PCA).

\begin{tabular}{|c|c|c|c|c|c|c|}
\hline \multirow{2}{*}{ Variables } & \multicolumn{5}{|c|}{ Components with varimax rotation } & \multirow{2}{*}{$M A X$} \\
\hline & 1 & 2 & 3 & 4 & 5 & \\
\hline$V 1$ & 0.34113 & 0.26302 & 0.66297 & 0.58299 & -0.05022 & 0.66297 \\
\hline$V 2$ & 0.34896 & 0.26021 & 0.66784 & 0.57574 & -0.05151 & 0.66784 \\
\hline$V 3$ & 0.31727 & 0.32061 & 0.78328 & -0.12012 & 0.10379 & 0.78328 \\
\hline V4 & -0.04091 & 0.07358 & 0.38066 & -0.87876 & 0.16099 & 0.87876 \\
\hline V5 & 0.04247 & 0.26658 & 0.12121 & -0.89684 & 0.07939 & 0.89684 \\
\hline V6 & -0.42566 & 0.13844 & -0.81646 & -0.07062 & -0.17234 & 0.81646 \\
\hline$V 7$ & 0.14292 & -0.09863 & -0.84993 & 0.37468 & -0.21257 & 0.84993 \\
\hline$V 8$ & 0.00095 & -0.53952 & -0.63721 & 0.41046 & 0.14770 & 0.63721 \\
\hline V9 & -0.23794 & -0.81430 & -0.14046 & 0.18364 & 0.22768 & 0.81430 \\
\hline$V 10$ & -0.30918 & -0.87356 & -0.02720 & -0.11355 & 0.05776 & 0.87356 \\
\hline V11 & 0.43849 & 0.39051 & 0.64343 & -0.00082 & -0.22098 & 0.64343 \\
\hline V12 & 0.41142 & 0.74691 & 0.42344 & 0.01714 & -0.02984 & 0.74691 \\
\hline$V 13$ & 0.17778 & 0.81124 & 0.41937 & -0.23043 & 0.00050 & 0.81124 \\
\hline V14 & -0.09838 & 0.89445 & 0.19113 & 0.02627 & -0.04940 & 0.89445 \\
\hline V15 & -0.46401 & 0.61269 & -0.12583 & -0.41281 & -0.10370 & 0.61269 \\
\hline V16 & 0.32087 & -0.03667 & 0.14227 & 0.77655 & 0.42541 & 0.77655 \\
\hline$V 17$ & 0.19781 & -0.26948 & 0.12132 & 0.07791 & 0.89855 & 0.89855 \\
\hline V18 & 0.58418 & -0.18393 & 0.05382 & -0.18640 & 0.71304 & 0.71304 \\
\hline V19 & 0.87701 & 0.02216 & 0.10819 & 0.06351 & -0.05253 & 0.87701 \\
\hline$V 20$ & 0.81933 & 0.27879 & -0.07938 & 0.15329 & -0.38694 & 0.81933 \\
\hline$V 21$ & 0.60624 & 0.10285 & 0.02294 & 0.48301 & -0.46828 & 0.60624 \\
\hline V22 & -0.85125 & -0.02353 & -0.05718 & -0.29759 & -0.27044 & 0.85125 \\
\hline V23 & -0.90583 & -0.10731 & -0.22230 & -0.25408 & -0.13261 & 0.90583 \\
\hline V24 & -0.92336 & -0.21466 & -0.21622 & -0.13789 & -0.04678 & 0.92336 \\
\hline V25 & -0.62228 & -0.43526 & -0.17578 & 0.26374 & 0.00948 & 0.62228 \\
\hline$V 26$ & 0.34338 & 0.56966 & -0.05678 & 0.03321 & -0.12820 & 0.56966 \\
\hline V27 & 0.77370 & 0.13584 & 0.45072 & -0.04507 & 0.15839 & 0.77370 \\
\hline V28 & 0.78681 & 0.07396 & 0.41789 & -0.15539 & 0.21332 & 0.78681 \\
\hline V29 & 0.85817 & 0.21523 & 0.27532 & 0.04560 & 0.25405 & 0.85817 \\
\hline V30 & 0.69720 & 0.21265 & 0.02949 & 0.09854 & 0.10256 & 0.69720 \\
\hline \multicolumn{6}{|c|}{ Minimum value } & 0.56966 \\
\hline
\end{tabular}


A New Method in Attribution? Attempts of the Employment of Geometric Morphometrics...

\section{Appendix 6}

Component matrix in case of 30 variables and 4 factors (PCA).

\begin{tabular}{|c|c|c|c|c|c|}
\hline \multirow{2}{*}{ Variables } & \multicolumn{4}{|c|}{ Components } & \multirow{2}{*}{$M A X$} \\
\hline & 1 & 2 & 3 & 4 & \\
\hline$V 1$ & 0.73656 & -0.12384 & -0.17537 & -0.61543 & 0.73656 \\
\hline$V 2$ & 0.74294 & -0.12294 & -0.16891 & -0.61132 & 0.74294 \\
\hline$V 3$ & 0.73297 & 0.32980 & 0.30919 & -0.31054 & 0.73297 \\
\hline$V 4$ & 0.09203 & 0.63784 & 0.68199 & 0.21678 & 0.68199 \\
\hline$V 5$ & 0.10852 & 0.68871 & 0.44956 & 0.45243 & 0.68871 \\
\hline V6 & -0.67081 & 0.12028 & -0.47169 & 0.41290 & 0.67081 \\
\hline$V 7$ & -0.29515 & -0.51033 & -0.62918 & 0.43357 & 0.62918 \\
\hline$V 8$ & -0.46059 & -0.77533 & -0.15052 & 0.18512 & 0.77533 \\
\hline$V 9$ & -0.54742 & -0.61421 & 0.34353 & -0.15222 & 0.61421 \\
\hline$V 10$ & -0.61593 & -0.38759 & 0.47320 & -0.10198 & 0.61593 \\
\hline$V 11$ & 0.78389 & 0.28852 & -0.03260 & -0.22682 & 0.78389 \\
\hline$V 12$ & 0.81905 & 0.41935 & -0.18268 & -0.07668 & 0.81905 \\
\hline$V 13$ & 0.63714 & 0.68758 & -0.06828 & -0.03819 & 0.68758 \\
\hline$V 14$ & 0.37383 & 0.65029 & -0.36897 & -0.14700 & 0.65029 \\
\hline$V 15$ & -0.22088 & 0.79835 & -0.17881 & 0.13555 & 0.79835 \\
\hline$V 16$ & 0.40776 & -0.64995 & -0.07921 & -0.38199 & 0.64995 \\
\hline$V 17$ & 0.16373 & -0.44653 & 0.66170 & -0.03738 & 0.66170 \\
\hline$V 18$ & 0.42960 & -0.36804 & 0.63031 & 0.33500 & 0.63031 \\
\hline$V 19$ & 0.74609 & -0.32512 & -0.01780 & 0.29031 & 0.74609 \\
\hline$V 20$ & 0.70750 & -0.17138 & -0.45629 & 0.35112 & 0.70750 \\
\hline$V 21$ & 0.54679 & -0.34896 & -0.55852 & -0.01132 & 0.55852 \\
\hline$V 22$ & -0.74699 & 0.52960 & -0.02647 & -0.18754 & 0.74699 \\
\hline$V 23$ & -0.88689 & 0.40167 & 0.00008 & -0.12512 & 0.88689 \\
\hline$V 24$ & -0.92393 & 0.25673 & 0.04012 & -0.20649 & 0.92393 \\
\hline$V 25$ & -0.71467 & -0.23492 & -0.01792 & -0.33214 & 0.71467 \\
\hline$V 26$ & 0.46798 & 0.22084 & -0.36937 & 0.20410 & 0.46798 \\
\hline$V 27$ & 0.87138 & -0.10507 & 0.25299 & 0.07655 & 0.87138 \\
\hline$V 28$ & 0.83320 & -0.10507 & 0.35787 & 0.16462 & 0.83320 \\
\hline$V 29$ & 0.90362 & -0.20477 & 0.15373 & 0.19073 & 0.90362 \\
\hline$V 30$ & 0.65981 & -0.20661 & -0.06632 & 0.25485 & 0.65981 \\
\hline \multicolumn{5}{|c|}{ Minimum value } & 0.46798 \\
\hline
\end{tabular}




\section{Appendix 7}

Relative variance with varimax rotation, in case of 30 variables and 4 factors (PCA).

\begin{tabular}{|c|c|c|c|c|}
\hline & $R C 1$ & $R C 2$ & $R C 3$ & $R C 4$ \\
\hline Relative variance & $30.20 \%$ & $20.20 \%$ & $17.00 \%$ & $14.20 \%$ \\
\hline E Relative variance & $30.20 \%$ & $50.50 \%$ & $67.40 \%$ & $81.60 \%$ \\
\hline
\end{tabular}

\section{Appendix 8}

Component matrix with varimax rotation, in case of 30 variables and 4 factors (PCA).

\begin{tabular}{|c|c|c|c|c|c|}
\hline \multirow{2}{*}{ Variables } & \multicolumn{4}{|c|}{ Components with varimax rotation } & \multirow{2}{*}{$M A X$} \\
\hline & 1 & 2 & 3 & 4 & \\
\hline$V 1$ & 0.31672 & 0.27820 & 0.64067 & 0.61579 & 0.64067 \\
\hline$V 2$ & 0.32416 & 0.27756 & 0.64416 & 0.61012 & 0.64416 \\
\hline$V 3$ & 0.34409 & 0.29126 & 0.79065 & -0.09845 & 0.79065 \\
\hline$V 4$ & 0.01681 & 0.04086 & 0.40172 & -0.87412 & 0.87412 \\
\hline$V 5$ & 0.08569 & 0.24588 & 0.14650 & -0.89646 & 0.89646 \\
\hline V6 & -0.44827 & 0.14038 & -0.78945 & -0.11639 & 0.78945 \\
\hline$V 7$ & 0.08139 & -0.02280 & -0.88230 & 0.38185 & 0.88230 \\
\hline$V 8$ & 0.00895 & -0.58526 & -0.62397 & 0.37183 & 0.62397 \\
\hline$V 9$ & -0.20853 & -0.85233 & -0.14424 & 0.16541 & 0.85233 \\
\hline V10 & -0.30995 & -0.80900 & -0.08447 & -0.07883 & 0.80900 \\
\hline$V 11$ & 0.39073 & 0.50727 & 0.57707 & 0.08505 & 0.57707 \\
\hline$V 12$ & 0.41489 & 0.71378 & 0.45168 & 0.01823 & 0.71378 \\
\hline$V 13$ & 0.20076 & 0.74786 & 0.47172 & -0.25045 & 0.74786 \\
\hline$V 14$ & -0.08311 & 0.80015 & 0.26892 & -0.03016 & 0.80015 \\
\hline$V 15$ & -0.44980 & 0.56026 & -0.06347 & -0.46503 & 0.56026 \\
\hline$V 16$ & 0.38769 & -0.24293 & 0.23276 & 0.69094 & 0.69094 \\
\hline V17 & 0.37975 & -0.65014 & 0.30296 & -0.08226 & 0.65014 \\
\hline$V 18$ & 0.72426 & -0.44414 & 0.17337 & -0.27867 & 0.72426 \\
\hline$V 19$ & 0.84330 & 0.11795 & 0.04226 & 0.14173 & 0.84330 \\
\hline$V 20$ & 0.71896 & 0.48596 & -0.19041 & 0.26853 & 0.71896 \\
\hline$V 21$ & 0.48155 & 0.34225 & -0.11242 & 0.60923 & 0.60923 \\
\hline$V 22$ & -0.88334 & 0.05199 & -0.07932 & -0.29165 & 0.88334 \\
\hline$V 23$ & -0.90994 & -0.10031 & -0.20821 & -0.28663 & 0.90994 \\
\hline$V 24$ & -0.91377 & -0.24198 & -0.18899 & -0.18589 & 0.91377 \\
\hline$V 25$ & -0.62255 & -0.45435 & -0.16992 & 0.23171 & 0.62255 \\
\hline$V 26$ & 0.32151 & 0.58198 & -0.04818 & 0.03840 & 0.58198 \\
\hline$V 27$ & 0.79423 & 0.12530 & 0.44005 & -0.00808 & 0.79423 \\
\hline$V 28$ & 0.81972 & 0.05021 & 0.41333 & -0.12303 & 0.81972 \\
\hline$V 29$ & 0.89741 & 0.14407 & 0.29995 & 0.04889 & 0.89741 \\
\hline V30 & 0.70594 & 0.18944 & 0.03600 & 0.10882 & 0.70594 \\
\hline \multicolumn{5}{|c|}{ Minimum value } & 0.56026 \\
\hline
\end{tabular}


A New Method in Attribution? Attempts of the Employment of Geometric Morphometrics...

\section{Appendix 9}

Relative variance in case of 28 variables and 5 or 4 factors (PCA) (not included: V11 and V26).

\begin{tabular}{|c|c|c|c|c|c|}
\hline & PC1 & PC2 & PC3 & PC4 & PC5 \\
\hline Relative variance & $41.20 \%$ & $20.80 \%$ & $12.90 \%$ & $0.86 \%$ & $0.45 \%$ \\
\hline E Relative variance & $41.20 \%$ & $62.00 \%$ & $74.90 \%$ & $83.50 \%$ & $88.00 \%$ \\
\hline
\end{tabular}

\section{Appendix 10}

Component matrix in case of 28 variables and 5 factors (PCA) (not included: V11 and V26).

\begin{tabular}{|c|c|c|c|c|c|c|}
\hline \multirow{2}{*}{ Variables } & \multicolumn{5}{|c|}{ Components } & \multirow{2}{*}{$M A X$} \\
\hline & 1 & 2 & 3 & 4 & 5 & \\
\hline$V 1$ & 0.73108 & -0.09807 & -0.21372 & -0.60754 & -0.03803 & 0.73108 \\
\hline$V 2$ & 0.74088 & -0.09339 & -0.21201 & -0.60346 & -0.05208 & 0.74088 \\
\hline$V 3$ & 0.71895 & 0.37815 & 0.27091 & -0.34262 & -0.14275 & 0.71895 \\
\hline$V 4$ & 0.07216 & 0.66798 & 0.66813 & 0.18106 & -0.18131 & 0.66813 \\
\hline V5 & 0.08264 & 0.71255 & 0.43718 & 0.43625 & -0.04447 & 0.71255 \\
\hline V6 & -0.68722 & 0.06463 & -0.42958 & 0.42196 & 0.25280 & 0.68722 \\
\hline$V 7$ & -0.27571 & -0.54500 & -0.58491 & 0.46342 & 0.13134 & 0.58491 \\
\hline$V 8$ & -0.40867 & -0.79193 & -0.11605 & 0.19717 & 0.15441 & 0.79193 \\
\hline$V 9$ & -0.50464 & -0.62662 & 0.36588 & -0.15050 & -0.08594 & 0.62662 \\
\hline$V 10$ & -0.59072 & -0.40745 & 0.50357 & -0.10260 & -0.34383 & 0.59072 \\
\hline$V 12$ & 0.79354 & 0.45699 & -0.22400 & -0.08458 & 0.12965 & 0.79354 \\
\hline$V 13$ & 0.60479 & 0.72376 & -0.11595 & -0.05836 & 0.15044 & 0.72376 \\
\hline$V 14$ & 0.34098 & 0.66370 & -0.41135 & -0.16764 & 0.31113 & 0.66370 \\
\hline$V 15$ & -0.26078 & 0.78414 & -0.20466 & 0.13423 & 0.24715 & 0.78414 \\
\hline$V 16$ & 0.43277 & -0.63776 & -0.06161 & -0.40439 & 0.39800 & 0.63776 \\
\hline V17 & 0.20415 & -0.40862 & 0.67814 & -0.08805 & 0.53478 & 0.67814 \\
\hline$V 18$ & 0.47223 & -0.31049 & 0.64810 & 0.28296 & 0.28479 & 0.64810 \\
\hline$V 19$ & 0.76533 & -0.28318 & -0.00365 & 0.27512 & -0.25480 & 0.76533 \\
\hline$V 20$ & 0.70162 & -0.15560 & -0.44440 & 0.37430 & -0.24360 & 0.70162 \\
\hline$V 21$ & 0.55483 & -0.33862 & -0.57287 & 0.03514 & -0.30138 & 0.57287 \\
\hline$V 22$ & -0.77197 & 0.49133 & -0.05541 & -0.15966 & -0.09934 & 0.77197 \\
\hline$V 23$ & -0.90830 & 0.35286 & -0.00313 & -0.11309 & 0.02626 & 0.90830 \\
\hline$V 24$ & -0.93602 & 0.20814 & 0.04355 & -0.20519 & 0.04485 & 0.93602 \\
\hline$V 25$ & -0.70169 & -0.27426 & 0.00324 & -0.34469 & -0.04247 & 0.70169 \\
\hline$V 27$ & 0.87994 & -0.04897 & 0.22809 & 0.08368 & -0.04244 & 0.87994 \\
\hline$V 28$ & 0.84326 & -0.04776 & 0.34064 & 0.16623 & -0.04493 & 0.84326 \\
\hline$V 29$ & 0.92053 & -0.14650 & 0.14529 & 0.17505 & 0.08712 & 0.92053 \\
\hline$V 30$ & 0.68781 & -0.15473 & -0.09085 & 0.25683 & 0.07043 & 0.68781 \\
\hline \multicolumn{6}{|c|}{ Minimum value } & 0.57287 \\
\hline
\end{tabular}




\section{Appendix 11}

Relative variance with varimax rotation, in case of 28 variables and 5 factors (PCA)(not included: V11 and V26).

\begin{tabular}{|c|c|c|c|c|c|}
\hline & $R C 1$ & $R C 2$ & $R C 3$ & $R C 4$ & $R C 5$ \\
\hline Relative variance & $31.90 \%$ & $18.50 \%$ & $15.10 \%$ & $14.10 \%$ & $0.84 \%$ \\
\hline E Relative variance & $31.90 \%$ & $50.40 \%$ & $65.50 \%$ & $79.50 \%$ & $88.00 \%$ \\
\hline
\end{tabular}

\section{Appendix 12}

Component matrix with varimax rotation, in case of 28 variables and 5 factors (PCA) (not included: V11 and V26).

\begin{tabular}{|c|c|c|c|c|c|c|}
\hline \multirow{2}{*}{ Variables } & \multicolumn{5}{|c|}{ Components with varimax rotation } & \multirow{2}{*}{$M A X$} \\
\hline & 1 & 2 & 3 & 4 & 5 & \\
\hline$V 1$ & 0.37171 & 0.28088 & 0.58142 & 0.63430 & -0.05377 & 0.63430 \\
\hline$V 2$ & 0.38245 & 0.28036 & 0.58956 & 0.62685 & -0.06365 & 0.62685 \\
\hline$V 3$ & 0.34938 & 0.33656 & 0.79278 & -0.05974 & 0.06021 & 0.79278 \\
\hline$V 4$ & -0.03574 & 0.10152 & 0.46501 & -0.84616 & 0.14015 & 0.84616 \\
\hline$V 5$ & 0.04589 & 0.29788 & 0.16378 & -0.87850 & 0.09246 & 0.87850 \\
\hline V6 & -0.44802 & 0.09588 & -0.80849 & -0.12829 & -0.15134 & 0.80849 \\
\hline$V 7$ & 0.12083 & -0.15732 & -0.88299 & 0.30405 & -0.18893 & 0.88299 \\
\hline$V 8$ & -0.02712 & -0.56680 & -0.63336 & 0.35266 & 0.15116 & 0.63336 \\
\hline$V 9$ & -0.26660 & -0.80863 & -0.09516 & 0.16193 & 0.22579 & 0.80863 \\
\hline$V 10$ & -0.34166 & -0.87050 & 0.05425 & -0.12762 & 0.05973 & 0.87050 \\
\hline$V 12$ & 0.44934 & 0.75800 & 0.36203 & 0.05831 & -0.04181 & 0.75800 \\
\hline$V 13$ & 0.21847 & 0.83272 & 0.39054 & -0.18604 & -0.02834 & 0.83272 \\
\hline V14 & -0.05749 & 0.90099 & 0.15567 & 0.05511 & -0.09230 & 0.90099 \\
\hline$V 15$ & -0.44682 & 0.64125 & -0.13283 & -0.40547 & -0.10470 & 0.64125 \\
\hline$V 16$ & 0.31422 & -0.06271 & 0.08424 & 0.78533 & 0.43962 & 0.78533 \\
\hline V17 & 0.17620 & -0.25530 & 0.13153 & 0.08922 & 0.91694 & 0.91694 \\
\hline$V 18$ & 0.57030 & -0.19644 & 0.09269 & -0.18682 & 0.70235 & 0.70235 \\
\hline$V 19$ & 0.88360 & -0.03291 & 0.11999 & 0.05863 & -0.08301 & 0.88360 \\
\hline V20 & 0.82832 & 0.22891 & -0.13113 & 0.14051 & -0.37142 & 0.82832 \\
\hline$V 21$ & 0.62471 & 0.08416 & -0.05493 & 0.47699 & -0.46353 & 0.62471 \\
\hline$V 22$ & -0.84586 & 0.03405 & -0.04113 & -0.29259 & -0.26802 & 0.84586 \\
\hline$V 23$ & -0.91451 & -0.07528 & -0.18744 & -0.26347 & -0.12832 & 0.91451 \\
\hline$V 24$ & -0.93472 & -0.19493 & -0.16623 & -0.15043 & -0.05926 & 0.93472 \\
\hline$V 25$ & -0.63616 & -0.45915 & -0.11317 & 0.24203 & -0.03619 & 0.63616 \\
\hline$V 27$ & 0.78700 & 0.16555 & 0.39152 & -0.00968 & 0.19328 & 0.78700 \\
\hline$V 28$ & 0.79404 & 0.10163 & 0.37305 & -0.12282 & 0.25294 & 0.79404 \\
\hline$V 29$ & 0.86907 & 0.20916 & 0.23642 & 0.06546 & 0.26264 & 0.86907 \\
\hline V30 & 0.71621 & 0.21452 & -0.01048 & 0.09921 & 0.08527 & 0.71621 \\
\hline \multicolumn{6}{|c|}{ Minimum value } & 0.62471 \\
\hline
\end{tabular}


A New Method in Attribution? Attempts of the Employment of Geometric Morphometrics...

\section{Appendix 13}

Component matrix in case of 28 variables and 4 factors (PCA) (not included: V11 and V26).

\begin{tabular}{|c|c|c|c|c|c|}
\hline \multirow{2}{*}{ Variables } & \multicolumn{4}{|c|}{ Components } & \multirow{2}{*}{$M A X$} \\
\hline & 1 & 2 & 3 & 4 & \\
\hline$V 1$ & 0.73108 & -0.09807 & -0.21372 & -0.60754 & 0.73108 \\
\hline$V 2$ & 0.74088 & -0.09339 & -0.21201 & -0.60346 & 0.74088 \\
\hline$V 3$ & 0.71895 & 0.37815 & 0.27091 & -0.34262 & 0.71895 \\
\hline$V 4$ & 0.07216 & 0.66798 & 0.66813 & 0.18106 & 0.66813 \\
\hline$V 5$ & 0.08264 & 0.71255 & 0.43718 & 0.43625 & 0.71255 \\
\hline V6 & -0.68722 & 0.06463 & -0.42958 & 0.42196 & 0.68722 \\
\hline$V 7$ & -0.27571 & -0.54500 & -0.58491 & 0.46342 & 0.58491 \\
\hline$V 8$ & -0.40867 & -0.79193 & -0.11605 & 0.19717 & 0.79193 \\
\hline$V 9$ & -0.50464 & -0.62662 & 0.36588 & -0.15050 & 0.62662 \\
\hline$V 10$ & -0.59072 & -0.40745 & 0.50357 & -0.10260 & 0.59072 \\
\hline$V 12$ & 0.79354 & 0.45699 & -0.22400 & -0.08458 & 0.79354 \\
\hline$V 13$ & 0.60479 & 0.72376 & -0.11595 & -0.05836 & 0.72376 \\
\hline$V 14$ & 0.34098 & 0.66370 & -0.41135 & -0.16764 & 0.66370 \\
\hline$V 15$ & -0.26078 & 0.78414 & -0.20466 & 0.13423 & 0.78414 \\
\hline$V 16$ & 0.43277 & -0.63776 & -0.06161 & -0.40439 & 0.63776 \\
\hline$V 17$ & 0.20415 & -0.40862 & 0.67814 & -0.08805 & 0.67814 \\
\hline$V 18$ & 0.47223 & -0.31049 & 0.64810 & 0.28296 & 0.64810 \\
\hline$V 19$ & 0.76533 & -0.28318 & -0.00365 & 0.27512 & 0.76533 \\
\hline$V 20$ & 0.70162 & -0.15560 & -0.44440 & 0.37430 & 0.70162 \\
\hline$V 21$ & 0.55483 & -0.33862 & -0.57287 & 0.03514 & 0.57287 \\
\hline$V 22$ & -0.77197 & 0.49133 & -0.05541 & -0.15966 & 0.77197 \\
\hline$V 23$ & -0.90830 & 0.35286 & -0.00313 & -0.11309 & 0.90830 \\
\hline$V 24$ & -0.93602 & 0.20814 & 0.04355 & -0.20519 & 0.93602 \\
\hline$V 25$ & -0.70169 & -0.27426 & 0.00324 & -0.34469 & 0.70169 \\
\hline$V 27$ & 0.87994 & -0.04897 & 0.22809 & 0.08368 & 0.87994 \\
\hline$V 28$ & 0.84326 & -0.04776 & 0.34064 & 0.16623 & 0.84326 \\
\hline$V 29$ & 0.92053 & -0.14650 & 0.14529 & 0.17505 & 0.92053 \\
\hline V30 & 0.68781 & -0.15473 & -0.09085 & 0.25683 & 0.68781 \\
\hline Minimu & $n$ value & & & & 0.57287 \\
\hline
\end{tabular}




\section{Appendix 14}

Relative variance with varimax rotation, in case of 28 variables and 4 factors (PCA) (not included: V11 and V26).

\begin{tabular}{|c|c|c|c|c|}
\hline & $R C 1$ & $R C 2$ & $R C 3$ & $R C 4$ \\
\hline Relative variance & $32.70 \%$ & $20.20 \%$ & $16.00 \%$ & $14.60 \%$ \\
\hline E Relative variance & $32.70 \%$ & $52.80 \%$ & $68.80 \%$ & $83.50 \%$ \\
\hline
\end{tabular}

\section{Appendix 15}

Component matrix with varimax rotation, in case of 28 variables and 4 factors. (PCA) (not included: V11 and V26).

\begin{tabular}{|c|c|c|c|c|c|}
\hline \multirow{2}{*}{ Variables } & \multicolumn{4}{|c|}{ Components with varimax rotation } & \multirow{2}{*}{$M A X$} \\
\hline & 1 & 2 & 3 & 4 & \\
\hline$V 1$ & 0.34962 & 0.30861 & 0.46796 & 0.72279 & 0.72279 \\
\hline$V 2$ & 0.35844 & 0.31419 & 0.47175 & 0.71902 & 0.71902 \\
\hline$V 3$ & 0.36703 & 0.35085 & 0.76767 & 0.05941 & 0.76767 \\
\hline$V 4$ & 0.01330 & 0.09757 & 0.56090 & -0.77864 & 0.77864 \\
\hline$V 5$ & 0.09789 & 0.27173 & 0.28320 & -0.85579 & 0.85579 \\
\hline V6 & -0.45331 & 0.07440 & -0.74890 & -0.25916 & 0.74890 \\
\hline$V 7$ & 0.07472 & -0.13244 & -0.93070 & 0.20148 & 0.93070 \\
\hline$V 8$ & -0.03233 & -0.63785 & -0.61401 & 0.24820 & 0.63785 \\
\hline$V 9$ & -0.26551 & -0.84148 & -0.08391 & 0.13495 & 0.84148 \\
\hline$V 10$ & -0.36691 & -0.79660 & 0.01665 & -0.09805 & 0.79660 \\
\hline$V 12$ & 0.46862 & 0.73160 & 0.36039 & 0.10559 & 0.73160 \\
\hline$V 13$ & 0.25423 & 0.79452 & 0.43474 & -0.14682 & 0.79452 \\
\hline$V 14$ & -0.02893 & 0.84325 & 0.20119 & 0.04107 & 0.84325 \\
\hline$V 15$ & -0.41334 & 0.60053 & -0.03145 & -0.45860 & 0.60053 \\
\hline$V 16$ & 0.36595 & -0.27375 & 0.14359 & 0.72930 & 0.72930 \\
\hline$V 17$ & 0.32493 & -0.63735 & 0.40539 & -0.01208 & 0.63735 \\
\hline$V 18$ & 0.68234 & -0.46128 & 0.29438 & -0.23340 & 0.68234 \\
\hline$V 19$ & 0.84774 & 0.05282 & 0.01277 & 0.14147 & 0.84774 \\
\hline$V 20$ & 0.75399 & 0.39053 & -0.29863 & 0.20945 & 0.75399 \\
\hline$V 21$ & 0.52090 & 0.29013 & -0.28993 & 0.55887 & 0.55887 \\
\hline$V 22$ & -0.86999 & 0.12986 & -0.04946 & -0.29951 & 0.86999 \\
\hline$V 23$ & -0.91701 & -0.04760 & -0.14296 & -0.31417 & 0.91701 \\
\hline$V 24$ & -0.93332 & -0.18878 & -0.11864 & -0.20653 & 0.93332 \\
\hline$V 25$ & -0.65991 & -0.43202 & -0.14063 & 0.21096 & 0.65991 \\
\hline$V 27$ & 0.81373 & 0.12031 & 0.39454 & 0.05847 & 0.81373 \\
\hline$V 28$ & 0.83118 & 0.03989 & 0.40124 & -0.05989 & 0.83118 \\
\hline$V 29$ & 0.90858 & 0.11339 & 0.26922 & 0.09867 & 0.90858 \\
\hline$V 30$ & 0.72727 & 0.17246 & -0.01390 & 0.11126 & 0.72727 \\
\hline \multicolumn{5}{|c|}{ Minimum value } & 0.55887 \\
\hline
\end{tabular}


A New Method in Attribution? Attempts of the Employment of Geometric Morphometrics...

\section{Appendix 16}

Relative variance in case of 26 variables and 5 or 4 factors (PCA) (not included: V6, V11, V21 and V26).

\begin{tabular}{|c|c|c|c|c|c|}
\hline & $P C 1$ & $P C 2$ & $P C 3$ & $P C 4$ & $P C 5$ \\
\hline Relative variance & $41.60 \%$ & $21.90 \%$ & $12.10 \%$ & $8.40 \%$ & $4.30 \%$ \\
\hline E Relative variance & $41.60 \%$ & $63.50 \%$ & $75.60 \%$ & $84.00 \%$ & $88.30 \%$ \\
\hline
\end{tabular}

\section{Appendix 17}

Component matrix in case of 26 variables and 5 factors (PCA) (not included: V6, V11, V21 and V26).

\begin{tabular}{|c|c|c|c|c|c|c|}
\hline \multirow{2}{*}{ Variables } & \multicolumn{5}{|c|}{ Components } & \multirow{2}{*}{$M A X$} \\
\hline & 1 & 2 & 3 & 4 & 5 & \\
\hline$V 1$ & 0.70615 & -0.10858 & -0.34542 & 0.56385 & -0.12117 & 0.70615 \\
\hline$V 2$ & 0.71478 & -0.10416 & -0.34665 & 0.55248 & -0.13002 & 0.71478 \\
\hline$V 3$ & 0.71974 & 0.33634 & 0.21208 & 0.39694 & -0.17810 & 0.71974 \\
\hline$V 4$ & 0.10083 & 0.62511 & 0.73933 & -0.04391 & -0.13243 & 0.73933 \\
\hline$V 5$ & 0.12119 & 0.67974 & 0.56517 & -0.33611 & 0.04166 & 0.67974 \\
\hline$V 7$ & -0.28327 & -0.50227 & -0.51072 & -0.57719 & 0.15636 & 0.57719 \\
\hline$V 8$ & -0.43689 & -0.76854 & -0.12873 & -0.23780 & 0.19068 & 0.76854 \\
\hline$V 9$ & -0.54110 & -0.62040 & 0.29511 & 0.19009 & -0.06000 & 0.62040 \\
\hline$V 10$ & -0.61737 & -0.40453 & 0.46527 & 0.16888 & -0.34731 & 0.61737 \\
\hline$V 12$ & 0.81340 & 0.43352 & -0.22008 & 0.07024 & 0.10300 & 0.81340 \\
\hline$V 13$ & 0.63703 & 0.69998 & -0.09573 & 0.05932 & 0.14261 & 0.69998 \\
\hline$V 14$ & 0.37051 & 0.66882 & -0.40609 & 0.11292 & 0.30694 & 0.66882 \\
\hline$V 15$ & -0.21625 & 0.79713 & -0.14054 & -0.16877 & 0.27944 & 0.79713 \\
\hline V16 & 0.40633 & -0.65708 & -0.20239 & 0.42197 & 0.32017 & 0.65708 \\
\hline$V 17$ & 0.20123 & -0.46984 & 0.59916 & 0.27335 & 0.52183 & 0.59916 \\
\hline$V 18$ & 0.47691 & -0.38033 & 0.65145 & -0.11280 & 0.28865 & 0.65145 \\
\hline$V 19$ & 0.75568 & -0.31494 & 0.02305 & -0.27774 & -0.29321 & 0.75568 \\
\hline$V 20$ & 0.69886 & -0.15714 & -0.37085 & -0.46096 & -0.26585 & 0.69886 \\
\hline$V 22$ & -0.75857 & 0.53084 & -0.04233 & 0.12027 & -0.05904 & 0.75857 \\
\hline$V 23$ & -0.89272 & 0.38944 & 0.00071 & 0.09098 & 0.04853 & 0.89272 \\
\hline$V 24$ & -0.92943 & 0.24359 & 0.01295 & 0.18329 & 0.06056 & 0.92943 \\
\hline$V 25$ & -0.72654 & -0.23809 & -0.07659 & 0.30659 & -0.03893 & 0.72654 \\
\hline$V 27$ & 0.87612 & -0.09909 & 0.22741 & -0.02098 & -0.05560 & 0.87612 \\
\hline$V 28$ & 0.84219 & -0.10325 & 0.36060 & -0.07264 & -0.04854 & 0.84219 \\
\hline$V 29$ & 0.92259 & -0.19789 & 0.16209 & -0.10097 & 0.05965 & 0.92259 \\
\hline$V 30$ & 0.68673 & -0.17908 & -0.04765 & -0.24681 & 0.09244 & 0.68673 \\
\hline \multicolumn{6}{|c|}{ Minimum value } & 0.57719 \\
\hline
\end{tabular}




\section{Appendix 18}

Relative variance with varimax rotation, in case of 26 variables and 5 factors (PCA) (not included: V6, V11, V21 and V26).

\begin{tabular}{|c|c|c|c|c|c|}
\hline & $R C 1$ & $R C 2$ & $R C 3$ & $R C 4$ & $R C 5$ \\
\hline Relative variance & $32.70 \%$ & $19.00 \%$ & $14.80 \%$ & $13.50 \%$ & $8.20 \%$ \\
\hline E Relative variance & $32.70 \%$ & $51.70 \%$ & $66.60 \%$ & $80.10 \%$ & $88.30 \%$ \\
\hline
\end{tabular}

\section{Appendix 19}

Component matrix with varimax rotation, in case of 26 variables and 5 factors (PCA)(not included: V6, V11, V21 and V26).

\begin{tabular}{|c|c|c|c|c|c|c|}
\hline \multirow{2}{*}{ Variables } & \multicolumn{5}{|c|}{ Components } & \multirow{2}{*}{$M A X$} \\
\hline & 1 & 2 & 3 & 4 & 5 & \\
\hline$V 1$ & 0.38665 & 0.25285 & 0.31887 & 0.80341 & -0.04215 & 0.80341 \\
\hline$V 2$ & 0.39834 & 0.25627 & 0.32005 & 0.79658 & -0.05246 & 0.79658 \\
\hline$V 3$ & 0.39163 & 0.29573 & 0.75724 & 0.22167 & 0.04496 & 0.75724 \\
\hline$V 4$ & 0.00551 & 0.07188 & 0.73764 & -0.63684 & 0.11019 & 0.73764 \\
\hline$V 5$ & 0.06607 & 0.29516 & 0.46199 & -0.77442 & 0.07884 & 0.77442 \\
\hline$V 7$ & 0.06630 & -0.10316 & -0.95304 & -0.02001 & -0.16497 & 0.95304 \\
\hline$V 8$ & -0.06978 & -0.51093 & -0.76307 & 0.08666 & 0.18790 & 0.76307 \\
\hline$V 9$ & -0.27660 & -0.78768 & -0.18473 & 0.09154 & 0.25506 & 0.78768 \\
\hline$V 10$ & -0.32915 & -0.88411 & 0.07862 & -0.10911 & 0.04842 & 0.88411 \\
\hline$V 12$ & 0.46328 & 0.73997 & 0.33407 & 0.19384 & -0.04661 & 0.73997 \\
\hline$V 13$ & 0.24029 & 0.81238 & 0.45647 & -0.02821 & -0.04402 & 0.81238 \\
\hline$V 14$ & -0.05839 & 0.89586 & 0.17392 & 0.11559 & -0.08299 & 0.89586 \\
\hline$V 15$ & -0.44339 & 0.64510 & 0.06260 & -0.41912 & -0.12717 & 0.64510 \\
\hline$V 16$ & 0.30542 & -0.06485 & -0.19774 & 0.75672 & 0.45737 & 0.75672 \\
\hline$V 17$ & 0.18485 & -0.25951 & 0.09274 & 0.10009 & 0.92040 & 0.92040 \\
\hline$V 18$ & 0.58532 & -0.19824 & 0.12182 & -0.16395 & 0.68476 & 0.68476 \\
\hline$V 19$ & 0.89794 & -0.04130 & 0.03546 & 0.10691 & -0.11491 & 0.89794 \\
\hline$V 20$ & 0.82052 & 0.23618 & -0.21359 & 0.10693 & -0.38433 & 0.82052 \\
\hline$V 22$ & -0.84564 & 0.03414 & 0.10296 & -0.28535 & -0.26202 & 0.84564 \\
\hline$V 23$ & -0.91488 & -0.07606 & -0.03739 & -0.30929 & -0.13929 & 0.91488 \\
\hline$V 24$ & -0.93458 & -0.19249 & -0.06801 & -0.20213 & -0.06810 & 0.93458 \\
\hline$V 25$ & -0.64774 & -0.44768 & -0.18818 & 0.17413 & -0.01430 & 0.64774 \\
\hline$V 27$ & 0.80604 & 0.15353 & 0.33095 & 0.12157 & 0.18726 & 0.80604 \\
\hline$V 28$ & 0.81315 & 0.08750 & 0.35729 & 0.00776 & 0.24700 & 0.81315 \\
\hline$V 29$ & 0.87919 & 0.19568 & 0.17830 & 0.14610 & 0.25683 & 0.87919 \\
\hline$V 30$ & 0.70361 & 0.23279 & -0.07797 & 0.08609 & 0.11248 & 0.70361 \\
\hline \multicolumn{6}{|c|}{ Minimum value } & 0.64510 \\
\hline
\end{tabular}


A New Method in Attribution? Attempts of the Employment of Geometric Morphometrics...

\section{Appendix 20}

Component matrix in case of 26 variables and 4 factors (PCA) (not included: V6, V11, V21 and V26).

\begin{tabular}{|c|c|c|c|c|c|}
\hline \multirow{2}{*}{ Variables } & \multicolumn{4}{|c|}{ Components } & \multirow{2}{*}{$M A X$} \\
\hline & 1 & 2 & 3 & 4 & \\
\hline$V 1$ & 0.70615 & -0.10858 & -0.34542 & 0.56385 & 0.70615 \\
\hline$V 2$ & 0.71478 & -0.10416 & -0.34665 & 0.55248 & 0.71478 \\
\hline$V 3$ & 0.71974 & 0.33634 & 0.21208 & 0.39694 & 0.71974 \\
\hline$V 4$ & 0.10083 & 0.62511 & 0.73933 & -0.04391 & 0.73933 \\
\hline$V 5$ & 0.12119 & 0.67974 & 0.56517 & -0.33611 & 0.67974 \\
\hline$V 7$ & -0.28327 & -0.50227 & -0.51072 & -0.57719 & 0.57719 \\
\hline$V 8$ & -0.43689 & -0.76854 & -0.12873 & -0.23780 & 0.76854 \\
\hline$V 9$ & -0.54110 & -0.62040 & 0.29511 & 0.19009 & 0.62040 \\
\hline$V 10$ & -0.61737 & -0.40453 & 0.46527 & 0.16888 & 0.61737 \\
\hline$V 12$ & 0.81340 & 0.43352 & -0.22008 & 0.07024 & 0.81340 \\
\hline$V 13$ & 0.63703 & 0.69998 & -0.09573 & 0.05932 & 0.69998 \\
\hline$V 14$ & 0.37051 & 0.66882 & -0.40609 & 0.11292 & 0.66882 \\
\hline$V 15$ & -0.21625 & 0.79713 & -0.14054 & -0.16877 & 0.79713 \\
\hline$V 16$ & 0.40633 & -0.65708 & -0.20239 & 0.42197 & 0.65708 \\
\hline$V 17$ & 0.20123 & -0.46984 & 0.59916 & 0.27335 & 0.59916 \\
\hline$V 18$ & 0.47691 & -0.38033 & 0.65145 & -0.11280 & 0.65145 \\
\hline$V 19$ & 0.75568 & -0.31494 & 0.02305 & -0.27774 & 0.75568 \\
\hline$V 20$ & 0.69886 & -0.15714 & -0.37085 & -0.46096 & 0.69886 \\
\hline$V 22$ & -0.75857 & 0.53084 & -0.04233 & 0.12027 & 0.75857 \\
\hline$V 23$ & -0.89272 & 0.38944 & 0.00071 & 0.09098 & 0.89272 \\
\hline$V 24$ & -0.92943 & 0.24359 & 0.01295 & 0.18329 & 0.92943 \\
\hline$V 25$ & -0.72654 & -0.23809 & -0.07659 & 0.30659 & 0.72654 \\
\hline$V 27$ & 0.87612 & -0.09909 & 0.22741 & -0.02098 & 0.87612 \\
\hline$V 28$ & 0.84219 & -0.10325 & 0.36060 & -0.07264 & 0.84219 \\
\hline$V 29$ & 0.92259 & -0.19789 & 0.16209 & -0.10097 & 0.92259 \\
\hline V30 & 0.68673 & -0.17908 & -0.04765 & -0.24681 & 0.68673 \\
\hline \multicolumn{5}{|c|}{ Minimum value } & 0.57719 \\
\hline
\end{tabular}




\section{Appendix 21}

Relative variance with varimax rotation, in case of 26 variables and 4 factors (PCA) (not included: V6, V11, V21 and V26)

\begin{tabular}{|c|c|c|c|c|}
\hline & $R C 1$ & $R C 2$ & $R C 3$ & $R C 4$ \\
\hline Relative variance & $33.70 \%$ & $20.90 \%$ & $15.50 \%$ & $13.90 \%$ \\
\hline E Relative variance & $33.70 \%$ & $54.60 \%$ & $70.10 \%$ & $84.00 \%$ \\
\hline
\end{tabular}

\section{Appendix 22}

Component matrix with varimax rotation, in case of 26 variables and 4 factors (PCA) (not included: V6, V11, V21 and V26).

\begin{tabular}{|c|c|c|c|c|c|}
\hline \multirow{2}{*}{ Variables } & \multicolumn{2}{|c}{ Components with varimax rotation } & \multirow{2}{*}{ MAX } \\
\cline { 2 - 5 } & 1 & 2 & 3 & 4 & \\
\hline V1 & 0.35695 & 0.30253 & 0.25395 & $\mathbf{0 . 8 1 5 0 1}$ & 0.81501 \\
\hline V2 & 0.36681 & 0.31094 & 0.25139 & $\mathbf{0 . 8 0 7 9 2}$ & 0.80792 \\
\hline V3 & 0.38756 & 0.32327 & $\mathbf{0 . 7 1 8 7 2}$ & 0.24984 & 0.71872 \\
\hline V4 & 0.03249 & 0.05945 & $\mathbf{0 . 7 5 5 6 9}$ & -0.61141 & 0.75569 \\
\hline V5 & 0.10814 & 0.24502 & 0.51502 & $\mathbf{- 0 . 7 5 6 4 1}$ & 0.75641 \\
\hline V7 & 0.04782 & -0.08983 & $\mathbf{- 0 . 9 5 5 7 8}$ & -0.05115 & 0.95578 \\
\hline V8 & -0.04864 & -0.60224 & -0.69562 & 0.07549 & 0.69562 \\
\hline V9 & -0.26648 & $\mathbf{- 0 . 8 3 5 0 1}$ & -0.15384 & 0.09486 & 0.83501 \\
\hline V10 & -0.36286 & $\mathbf{- 0 . 8 0 3 5 6}$ & 0.01830 & -0.10987 & 0.80356 \\
\hline V12 & 0.47544 & $\mathbf{0 . 7 2 0 4 6}$ & 0.33866 & 0.20768 & 0.72046 \\
\hline V13 & 0.26518 & $\mathbf{0 . 7 7 8 0 4}$ & 0.48225 & -0.01492 & 0.77804 \\
\hline V14 & -0.02801 & $\mathbf{0 . 8 3 4 9 9}$ & 0.22650 & 0.11390 & 0.83499 \\
\hline V15 & -0.41121 & 0.59955 & 0.12398 & -0.43183 & 0.59955 \\
\hline V16 & 0.36608 & -0.26364 & -0.07678 & $\mathbf{0 . 7 7 8 7 6}$ & 0.77876 \\
\hline V17 & 0.33663 & -0.65065 & 0.36785 & 0.15158 & 0.65065 \\
\hline V18 & 0.69409 & -0.46920 & 0.30647 & -0.11559 & 0.69409 \\
\hline V19 & $\mathbf{0 . 8 5 1 5 9}$ & 0.06478 & -0.06677 & 0.11857 & 0.85159 \\
\hline V20 & $\mathbf{0 . 7 4 5 6 4}$ & 0.41126 & -0.35854 & 0.09722 & 0.74564 \\
\hline V22 & $\mathbf{- 0 . 8 7 0 5 7}$ & 0.12079 & 0.06588 & -0.31090 & 0.87057 \\
\hline V23 & $\mathbf{- 0 . 9 1 7 8 3}$ & -0.04993 & -0.02798 & -0.33348 & 0.91783 \\
\hline V24 & $\mathbf{- 0 . 9 3 2 5 5}$ & -0.18679 & -0.04696 & -0.22402 & 0.93255 \\
\hline V25 & -0.66379 & -0.42433 & -0.19794 & 0.15670 & 0.66379 \\
\hline V27 & $\mathbf{0 . 8 2 3 8 4}$ & 0.11063 & 0.33902 & 0.15388 & 0.82384 \\
\hline $\mathbf{0 . 8 4 0 9 0}$ & 0.02448 & 0.38157 & 0.04409 & 0.84090 \\
\hline $\mathbf{0 . 9 1 3 6 4}$ & 0.10452 & 0.22137 & 0.17924 & 0.91364 \\
\hline V28 & $\mathbf{0 . 7 2 3 2 6}$ & 0.17516 & -0.05084 & 0.10235 & 0.72326 \\
\hline value & & & & 0.59955 \\
\hline
\end{tabular}


A New Method in Attribution? Attempts of the Employment of Geometric Morphometrics...

\section{Appendix 23}

Relative variance in case of 24 variables and 5 or 4 factors (PCA) (not included: V6, V11, V15, V21, V26 and V30)

\begin{tabular}{|c|c|c|c|c|c|}
\hline & PC1 & PC2 & PC3 & PC4 & PC5 \\
\hline Relative variance & $43.00 \%$ & $21.10 \%$ & $13.00 \%$ & $8.80 \%$ & $4.30 \%$ \\
\hline S Relative variance & $43.00 \%$ & $64.10 \%$ & $77.20 \%$ & $86.00 \%$ & $90.30 \%$ \\
\hline
\end{tabular}

\section{Appendix 24}

Component matrix in case of 24 variables and 5 factors (PCA) (not included: V6, V11, V15, V21, V26 and V30).

\begin{tabular}{|c|c|c|c|c|c|c|}
\hline \multirow{2}{*}{ Variables } & \multicolumn{5}{|c|}{ Components } & \multirow{2}{*}{$M A X$} \\
\hline & 1 & 2 & 3 & 4 & 5 & \\
\hline$V 1$ & 0.70852 & 0.14642 & -0.35866 & 0.53782 & -0.15864 & 0.70852 \\
\hline$V 2$ & 0.71685 & 0.14356 & -0.35930 & 0.52756 & -0.16979 & 0.71685 \\
\hline$V 3$ & 0.73893 & -0.32816 & 0.18061 & 0.38102 & -0.19219 & 0.73893 \\
\hline$V 4$ & 0.13412 & -0.65797 & 0.70733 & -0.04663 & -0.11383 & 0.70733 \\
\hline$V 5$ & 0.15442 & -0.68887 & 0.54321 & -0.34014 & 0.08993 & 0.68887 \\
\hline$V 7$ & -0.31408 & 0.53581 & -0.46435 & -0.57352 & 0.18245 & 0.57352 \\
\hline$V 8$ & -0.48350 & 0.76336 & -0.07989 & -0.19698 & 0.16156 & 0.76336 \\
\hline$V 9$ & -0.57773 & 0.55206 & 0.31232 & 0.22627 & -0.09149 & 0.57773 \\
\hline$V 10$ & -0.63434 & 0.33115 & 0.47052 & 0.18257 & -0.39395 & 0.63434 \\
\hline$V 12$ & 0.83092 & -0.38557 & -0.24075 & 0.05129 & 0.13464 & 0.83092 \\
\hline$V 13$ & 0.67411 & -0.65826 & -0.12813 & 0.03368 & 0.18664 & 0.67411 \\
\hline$V 14$ & 0.40725 & -0.61866 & -0.43489 & 0.09159 & 0.35004 & 0.61866 \\
\hline$V 16$ & 0.37883 & 0.69124 & -0.17770 & 0.44158 & 0.26928 & 0.69124 \\
\hline$V 17$ & 0.18162 & 0.46867 & 0.62310 & 0.33068 & 0.46581 & 0.62310 \\
\hline$V 18$ & 0.45401 & 0.38879 & 0.67960 & -0.06868 & 0.26141 & 0.67960 \\
\hline$V 19$ & 0.73500 & 0.35031 & 0.04348 & -0.29485 & -0.29277 & 0.73500 \\
\hline$V 20$ & 0.68545 & 0.21599 & -0.35106 & -0.49599 & -0.23721 & 0.68545 \\
\hline$V 22$ & -0.73488 & -0.58082 & -0.07424 & 0.12316 & -0.04772 & 0.73488 \\
\hline$V 23$ & -0.86754 & -0.43242 & -0.02103 & 0.09319 & 0.05698 & 0.86754 \\
\hline$V 24$ & -0.90952 & -0.29115 & -0.00515 & 0.18838 & 0.06194 & 0.90952 \\
\hline$V 25$ & -0.72766 & 0.19604 & -0.07903 & 0.30356 & -0.04736 & 0.72766 \\
\hline$V 27$ & 0.87718 & 0.14816 & 0.23609 & -0.03270 & -0.08143 & 0.87718 \\
\hline$V 28$ & 0.84371 & 0.13827 & 0.36763 & -0.08803 & -0.05164 & 0.84371 \\
\hline$V 29$ & 0.90542 & 0.23538 & 0.17611 & -0.09542 & 0.05927 & 0.90542 \\
\hline Minimu & a value & & & & & 0.57352 \\
\hline
\end{tabular}




\section{Appendix 25}

Relative variance with varimax rotation, in case of 24 variables and 5 factors (PCA) (not included: V6, V11, V15, V21, V26 and V30).

\begin{tabular}{|c|c|c|c|c|c|}
\hline & $\mathrm{RC} 1$ & $\mathrm{RC} 2$ & $\mathrm{RC} 3$ & $\mathrm{RC} 4$ & $\mathrm{RC} 5$ \\
\hline Relative variance & $31,90 \%$ & $20,10 \%$ & $15,40 \%$ & $13,80 \%$ & $9,10 \%$ \\
\hline$\Sigma$ Relative variance & $31,90 \%$ & $52,00 \%$ & $67,40 \%$ & $81,20 \%$ & $90,30 \%$ \\
\hline
\end{tabular}

\section{Appendix 26}

Component matrix with varimax rotation, in case of 24 variables and 5 factors (PCA) (not included: V6, V11, V15, V21, V26 and V30).

\begin{tabular}{|c|c|c|c|c|c|c|}
\hline \multirow{2}{*}{ Variables } & \multicolumn{5}{|c|}{ Components } & \multirow{2}{*}{$M A X$} \\
\hline & 1 & 2 & 3 & 4 & 5 & \\
\hline$V 1$ & 0.39171 & 0.28331 & 0.31825 & 0.79393 & -0.03441 & 0.79393 \\
\hline$V 2$ & 0.40370 & 0.28441 & 0.32068 & 0.78862 & -0.04574 & 0.78862 \\
\hline$V 3$ & 0.39170 & 0.32657 & 0.75073 & 0.20532 & 0.05104 & 0.75073 \\
\hline$V 4$ & 0.01755 & 0.07238 & 0.72534 & -0.65068 & 0.10633 & 0.72534 \\
\hline$V 5$ & 0.05737 & 0.29992 & 0.43877 & -0.79087 & 0.07752 & 0.79087 \\
\hline$V 7$ & 0.05244 & -0.10650 & -0.96153 & -0.00594 & -0.15778 & 0.96153 \\
\hline$V 8$ & -0.07042 & -0.52724 & -0.74684 & 0.11003 & 0.18696 & 0.74684 \\
\hline V9 & -0.26068 & -0.78896 & -0.16341 & 0.10363 & 0.26041 & 0.78896 \\
\hline$V 10$ & -0.27383 & -0.90930 & 0.09878 & -0.09345 & 0.04089 & 0.90930 \\
\hline$V 12$ & 0.42016 & 0.78118 & 0.31617 & 0.17269 & -0.03534 & 0.78118 \\
\hline$V 13$ & 0.20515 & 0.83957 & 0.43460 & -0.05309 & -0.03821 & 0.83957 \\
\hline$V 14$ & -0.10275 & 0.90264 & 0.16360 & 0.09727 & -0.08423 & 0.90264 \\
\hline$V 16$ & 0.30034 & -0.03572 & -0.19638 & 0.75480 & 0.46972 & 0.75480 \\
\hline$V 17$ & 0.18560 & -0.24516 & 0.09289 & 0.09669 & 0.92450 & 0.92450 \\
\hline$V 18$ & 0.58122 & -0.16425 & 0.10563 & -0.16912 & 0.69831 & 0.69831 \\
\hline$V 19$ & 0.90454 & 0.00883 & 0.00846 & 0.10282 & -0.09255 & 0.90454 \\
\hline$V 20$ & 0.81276 & 0.27973 & -0.24429 & 0.10285 & -0.36458 & 0.81276 \\
\hline$V 22$ & -0.84956 & -0.02218 & 0.13551 & -0.27620 & -0.28889 & 0.84956 \\
\hline$V 23$ & -0.90345 & -0.13679 & -0.01316 & -0.30000 & -0.16397 & 0.90345 \\
\hline$V 24$ & -0.91785 & -0.24932 & -0.04346 & -0.19241 & -0.08851 & 0.91785 \\
\hline$V 25$ & -0.61853 & -0.47159 & -0.17531 & 0.18069 & -0.01428 & 0.61853 \\
\hline$V 27$ & 0.82138 & 0.19031 & 0.30460 & 0.11089 & 0.19720 & 0.82138 \\
\hline$V 28$ & 0.82649 & 0.14228 & 0.31893 & -0.01176 & 0.26711 & 0.82649 \\
\hline$V 29$ & 0.85688 & 0.25724 & 0.15317 & 0.13150 & 0.27867 & 0.85688 \\
\hline \multicolumn{6}{|c|}{ Minimum value } & 0.61853 \\
\hline
\end{tabular}


A New Method in Attribution? Attempts of the Employment of Geometric Morphometrics...

\section{Appendix 27}

Component matrix in case of 24 variables and 4 factors (PCA) (not included: V6, V11, V15, V21, V26 and V30).

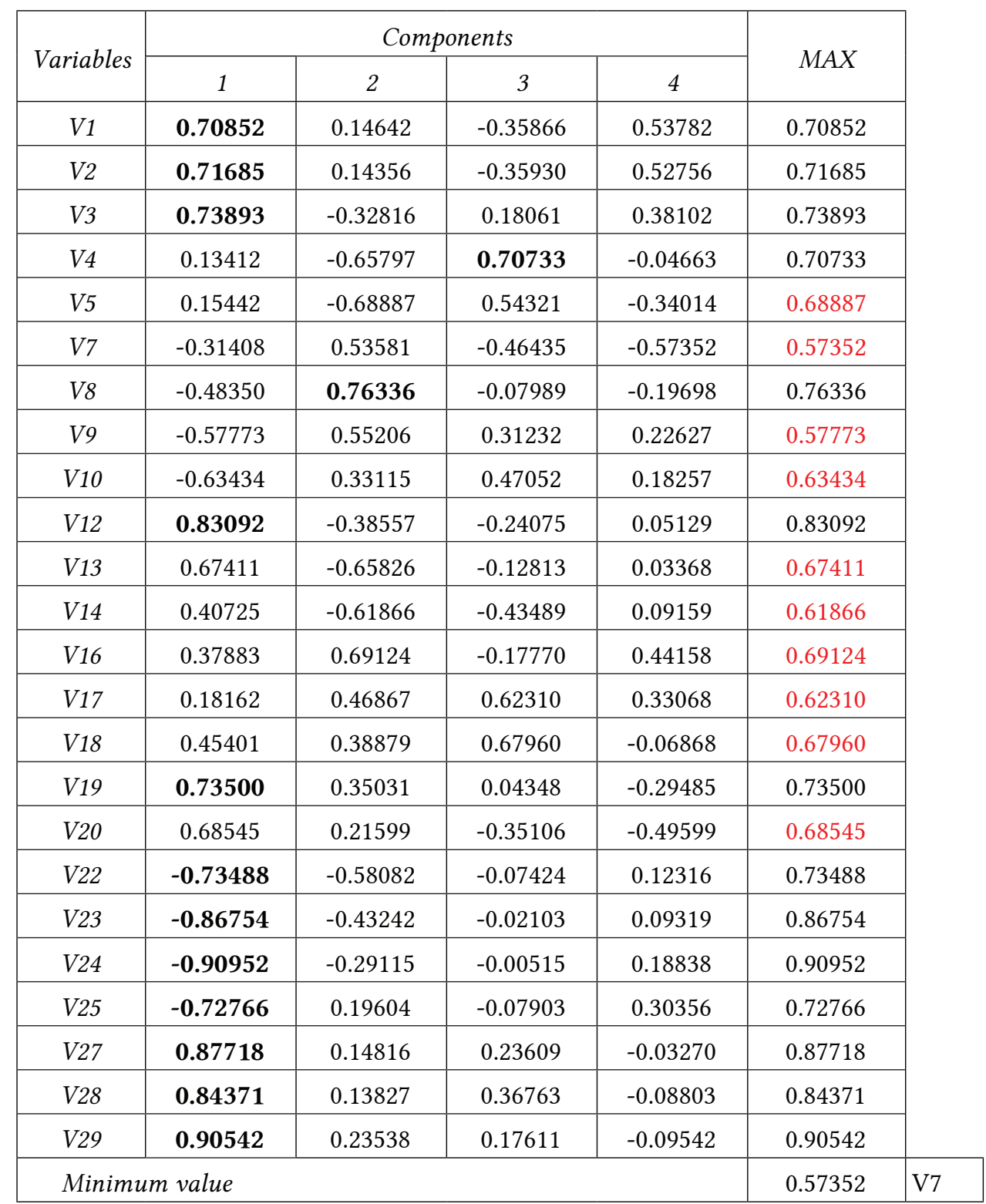




\section{Appendix 28}

Relative variance with varimax rotation, in case of 24 variables and 4 factors (PCA) (not included: V6, V11, V15, V21, V26 and V30).

\begin{tabular}{|c|c|c|c|c|}
\hline & $R C 1$ & $R C 2$ & $R C 3$ & $R C 4$ \\
\hline Relative variance & $33.30 \%$ & $22.40 \%$ & $16.00 \%$ & $14.20 \%$ \\
\hline I Relative variance & $33.30 \%$ & $55.80 \%$ & $71.80 \%$ & $86.00 \%$ \\
\hline
\end{tabular}

\section{Appendix 29}

Component matrix with varimax rotation, in case of 24 variables and 4 factors (PCA) (not included: V6, V11, V15, V21, V26 and V30).

\begin{tabular}{|c|c|c|c|c|c|}
\hline \multirow{2}{*}{ Variables } & \multicolumn{2}{|c}{ Components with varimax rotation } & \multirow{2}{*}{ MAX } \\
\cline { 2 - 5 } & 1 & 2 & 3 & 4 & \\
\hline V1 & 0.35161 & 0.34654 & 0.23557 & $\mathbf{0 . 8 0 1 3 2}$ & 0.80132 \\
\hline V2 & 0.36035 & 0.35438 & 0.23303 & $\mathbf{0 . 7 9 5 0 8}$ & 0.79508 \\
\hline V3 & 0.38830 & 0.37025 & 0.69985 & 0.23204 & 0.69985 \\
\hline V4 & 0.05745 & 0.06810 & $\mathbf{0 . 7 4 6 1 1}$ & -0.62353 & 0.74611 \\
\hline V5 & 0.11106 & 0.24745 & 0.50185 & $\mathbf{- 0 . 7 6 4 0 3}$ & 0.76403 \\
\hline V7 & 0.02053 & -0.10530 & $\mathbf{- 0 . 9 5 7 7 4}$ & -0.03881 & 0.95774 \\
\hline V8 & -0.03834 & -0.62394 & -0.67865 & 0.10168 & 0.67865 \\
\hline V9 & -0.22740 & $\mathbf{- 0 . 8 4 1 7 3}$ & -0.12791 & 0.10351 & 0.84173 \\
\hline V10 & -0.30322 & $\mathbf{- 0 . 8 1 3 0 5}$ & 0.03164 & -0.11309 & 0.81305 \\
\hline V12 & 0.42787 & $\mathbf{0 . 7 5 8 6 9}$ & 0.31998 & 0.19651 & 0.75869 \\
\hline V13 & 0.22895 & $\mathbf{0 . 7 9 7 0 4}$ & 0.46572 & -0.02634 & 0.79704 \\
\hline V14 & -0.07583 & $\mathbf{0 . 8 2 2 0 6}$ & 0.22702 & 0.11420 & 0.82206 \\
\hline V16 & 0.38955 & -0.24125 & -0.08153 & $\mathbf{0 . 7 9 4 5 4}$ & 0.79454 \\
\hline V17 & 0.40405 & -0.64572 & 0.36975 & 0.18252 & 0.64572 \\
\hline V18 & $\mathbf{0 . 7 3 8 0 5}$ & -0.43229 & 0.28712 & -0.09911 & 0.73805 \\
\hline V19 & $\mathbf{0 . 8 4 2 6 0}$ & 0.13941 & -0.11172 & 0.09936 & 0.84260 \\
\hline V20 & $\mathbf{0 . 7 0 2 5 0}$ & 0.47317 & -0.40330 & 0.07545 & 0.70250 \\
\hline V22 & $\mathbf{- 0 . 8 8 8 2 0}$ & 0.05666 & 0.10887 & -0.30679 & 0.88820 \\
\hline V23 & $\mathbf{- 0 . 9 1 0 0 3}$ & -0.12465 & 0.01035 & -0.32396 & 0.91003 \\
\hline V24 & $\mathbf{- 0 . 9 1 3 3 7}$ & -0.26036 & -0.00739 & -0.21310 & 0.91337 \\
\hline V25 & -0.62849 & -0.46452 & -0.17369 & 0.15927 & 0.62849 \\
\hline V27 & $\mathbf{0 . 8 4 3 8 5}$ & 0.17135 & 0.29305 & 0.14453 & 0.84385 \\
\hline V28 & $\mathbf{0 . 8 6 8 3 3}$ & 0.09411 & 0.33197 & 0.02833 & 0.86833 \\
\hline M29 & $\mathbf{0 . 9 0 5 4 7}$ & 0.17563 & 0.18658 & 0.17259 & 0.90547 \\
\hline & value & & & & 0.62849 \\
\hline & & & & \\
\hline
\end{tabular}


A New Method in Attribution? Attempts of the Employment of Geometric Morphometrics...

\section{Appendix 30}

Relative variance in case of 22 variables and 4 or 3 factors (PCA) (not included: V6, V10, V11, V15, V21, V25, V26 and V30).

\begin{tabular}{|c|c|c|c|c|}
\hline & $P C 1$ & $P C 2$ & $P C 3$ & $P C 4$ \\
\hline Relative variance & $43.10 \%$ & $22.40 \%$ & $13.30 \%$ & $9.00 \%$ \\
\hline R Relative variance & $43.10 \%$ & $65.40 \%$ & $78.70 \%$ & $87.70 \%$ \\
\hline
\end{tabular}

\section{Appendix 31}

Component matrix in case of 22 variables and 4 factors (PCA) (not included: V6, V10, V11, V15, V21, V25, V26 and V30).

\begin{tabular}{|c|c|c|c|c|c|}
\hline \multirow{2}{*}{ Variables } & \multicolumn{4}{|c|}{ Components } & \multirow{2}{*}{ MAX } \\
\cline { 2 - 5 } & 1 & 2 & 3 & 4 & \\
\hline V1 & $\mathbf{0 . 7 2 8 3 6}$ & -0.09682 & -0.42744 & 0.47564 & 0.72836 \\
\hline V2 & $\mathbf{0 . 7 3 6 8 5}$ & -0.09366 & -0.42490 & 0.46159 & 0.73685 \\
\hline V3 & $\mathbf{0 . 7 4 2 6 5}$ & 0.41282 & 0.09303 & 0.31536 & 0.74265 \\
\hline V4 & 0.11581 & $\mathbf{0 . 7 1 8 2 6}$ & 0.64999 & -0.05461 & 0.71826 \\
\hline V5 & 0.10607 & $\mathbf{0 . 7 1 6 1 6}$ & 0.52465 & -0.32536 & 0.71616 \\
\hline V7 & -0.31732 & -0.61669 & -0.35434 & -0.54777 & 0.61669 \\
\hline V8 & -0.43906 & $\mathbf{- 0 . 8 0 8 5 2}$ & 0.01576 & -0.14072 & 0.80852 \\
\hline V9 & -0.52113 & -0.55959 & 0.35149 & 0.29769 & 0.55959 \\
\hline V12 & $\mathbf{0 . 7 8 9 0 9}$ & 0.41773 & -0.27494 & -0.00201 & 0.78909 \\
\hline V13 & 0.61726 & 0.68593 & -0.17194 & -0.01774 & 0.68593 \\
\hline V14 & 0.34412 & 0.60612 & -0.45840 & 0.04206 & 0.60612 \\
\hline V16 & 0.43034 & -0.66437 & -0.15868 & 0.46543 & 0.66437 \\
\hline V17 & 0.23582 & -0.40948 & 0.65401 & 0.42345 & 0.65401 \\
\hline V18 & 0.49586 & -0.31692 & $\mathbf{0 . 7 1 6 1 8}$ & -0.01262 & 0.71618 \\
\hline V19 & $\mathbf{0 . 7 6 0 5 1}$ & -0.29560 & 0.04411 & -0.34985 & 0.76051 \\
\hline V20 & 0.67393 & -0.20717 & -0.33666 & -0.55753 & 0.67393 \\
\hline V22 & $\mathbf{- 0 . 7 7 6 9 5}$ & 0.52485 & -0.10384 & 0.13880 & 0.77695 \\
\hline V23 & $\mathbf{- 0 . 8 9 7 1 3}$ & 0.37046 & -0.02691 & 0.12440 & 0.89713 \\
\hline V24 & $\mathbf{- 0 . 9 2 0 6 3}$ & 0.23387 & 0.00118 & 0.21585 & 0.92063 \\
\hline V27 & $\mathbf{0 . 8 8 8 4 2}$ & -0.07384 & 0.21000 & -0.04223 & 0.88842 \\
\hline V28 & $\mathbf{0 . 8 5 5 9 3}$ & -0.05925 & 0.34229 & -0.08388 & 0.85593 \\
\hline V29 & $\mathbf{0 . 9 1 4 9 2}$ & -0.16865 & 0.16599 & -0.09503 & 0.91492 \\
\hline Minimum value & & & & 0.55959 \\
\hline & & & & \\
\hline
\end{tabular}




\section{Appendix 32}

Relative variance with varimax rotation, in case of 22 variables and 4 factors (PCA) (not included: V6, V10, V11, V15, V21, V25, V26 and V30).

\begin{tabular}{|c|c|c|c|c|}
\hline & $R C 1$ & $R C 2$ & $R C 3$ & $R C 4$ \\
\hline Relative variance & $34.20 \%$ & $26.30 \%$ & $15.30 \%$ & $11.90 \%$ \\
\hline E Relative variance & $34.20 \%$ & $60.50 \%$ & $75.80 \%$ & $87.70 \%$ \\
\hline
\end{tabular}

\section{Appendix 33}

Component matrix with varimax rotation, in case of 22 variables and 4 factors (PCA) (not included: V6, V10, V11, V15, V21, V25, V26 and V30).

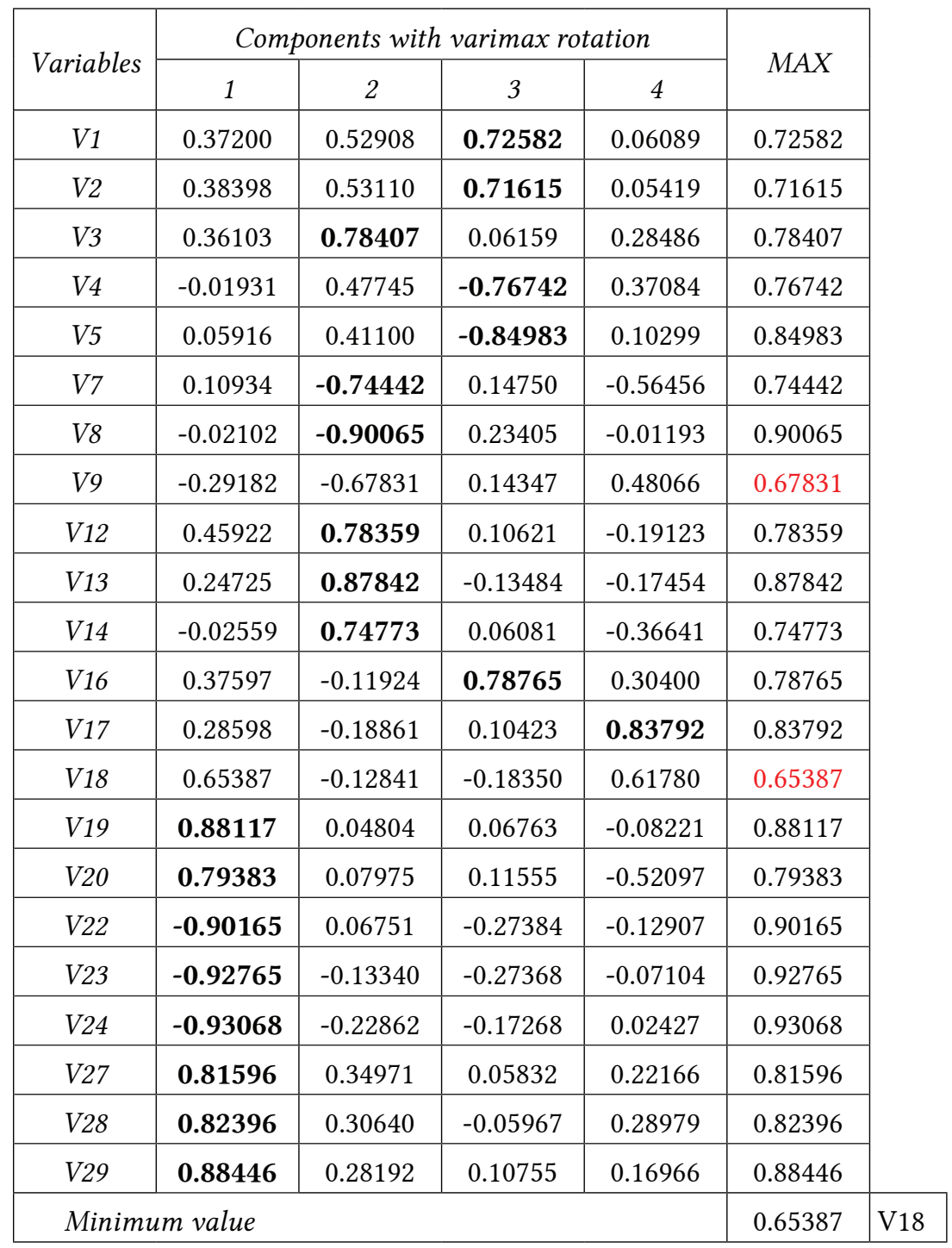


A New Method in Attribution? Attempts of the Employment of Geometric Morphometrics...

\section{Appendix 34}

Component matrix in case of 22 variables and 3 factors (PCA) (not included: V6, V10, V11, V15, V21, V25, V26 and V30).

\begin{tabular}{|c|c|c|c|c|}
\hline \multirow{2}{*}{ Variables } & \multicolumn{3}{|c|}{ Components } & \multirow{2}{*}{$M A X$} \\
\hline & 1 & 2 & 3 & \\
\hline$V 1$ & 0.72836 & -0.09682 & -0.42744 & 0.72836 \\
\hline$V 2$ & 0.73685 & -0.09366 & -0.42490 & 0.73685 \\
\hline$V 3$ & 0.74265 & 0.41282 & 0.09303 & 0.74265 \\
\hline$V 4$ & 0.11581 & 0.71826 & 0.64999 & 0.71826 \\
\hline V5 & 0.10607 & 0.71616 & 0.52465 & 0.71616 \\
\hline$V 7$ & -0.31732 & -0.61669 & -0.35434 & 0.61669 \\
\hline$V 8$ & -0.43906 & -0.80852 & 0.01576 & 0.80852 \\
\hline$V 9$ & -0.52113 & -0.55959 & 0.35149 & 0.55959 \\
\hline$V 12$ & 0.78909 & 0.41773 & -0.27494 & 0.78909 \\
\hline$V 13$ & 0.61726 & 0.68593 & -0.17194 & 0.68593 \\
\hline$V 14$ & 0.34412 & 0.60612 & -0.45840 & 0.60612 \\
\hline$V 16$ & 0.43034 & -0.66437 & -0.15868 & 0.66437 \\
\hline$V 17$ & 0.23582 & -0.40948 & 0.65401 & 0.65401 \\
\hline$V 18$ & 0.49586 & -0.31692 & 0.71618 & 0.71618 \\
\hline$V 19$ & 0.76051 & -0.29560 & 0.04411 & 0.76051 \\
\hline$V 20$ & 0.67393 & -0.20717 & -0.33666 & 0.67393 \\
\hline$V 22$ & -0.77695 & 0.52485 & -0.10384 & 0.77695 \\
\hline$V 23$ & -0.89713 & 0.37046 & -0.02691 & 0.89713 \\
\hline$V 24$ & -0.92063 & 0.23387 & 0.00118 & 0.92063 \\
\hline$V 27$ & 0.88842 & -0.07384 & 0.21000 & 0.88842 \\
\hline$V 28$ & 0.85593 & -0.05925 & 0.34229 & 0.85593 \\
\hline$V 29$ & 0.91492 & -0.16865 & 0.16599 & 0.91492 \\
\hline \multicolumn{4}{|c|}{ Minimum value } & 0.55959 \\
\hline
\end{tabular}

\section{Appendix 35}

Relative variance with varimax rotation, in case of 22 variables and 3 factors (PCA) (not included: V6, V10, V11, V15, V21, V25, V26 and V30).

\begin{tabular}{|c|c|c|c|}
\hline & $R C 1$ & $R C 2$ & $R C 3$ \\
\hline Relative variance & $38.60 \%$ & $21.50 \%$ & $18.60 \%$ \\
\hline SRelative variance & $38.60 \%$ & $60.10 \%$ & $78.70 \%$ \\
\hline
\end{tabular}




\section{Appendix 36}

Component matrix with varimax rotation, in case of 22 variables and 3 factors (PCA) (not included: V6, V10, V11, V15, V21, V25, V26 and V30).

\begin{tabular}{|c|c|c|c|c|}
\hline \multirow{2}{*}{ Variables } & \multicolumn{3}{|c|}{ Components with varimax rota- } & \multirow{2}{*}{ MAX } \\
\cline { 2 - 4 } & 1 & 2 & 3 & \\
\hline V1 & 0.61011 & 0.54024 & -0.24187 & 0.61011 \\
\hline V2 & 0.61692 & 0.54383 & -0.23647 & 0.61692 \\
\hline V3 & 0.51675 & 0.48433 & 0.47853 & 0.51675 \\
\hline V4 & -0.06174 & 0.01869 & $\mathbf{0 . 9 7 3 4 7}$ & 0.97347 \\
\hline V5 & -0.09342 & 0.10060 & $\mathbf{0 . 8 8 3 4 8}$ & 0.88348 \\
\hline V7 & -0.10345 & -0.24747 & $\mathbf{- 0 . 7 3 1 1 7}$ & 0.73117 \\
\hline V8 & -0.06503 & -0.66794 & -0.62956 & 0.66794 \\
\hline V9 & -0.17490 & $\mathbf{- 0 . 7 8 8 6 2}$ & -0.23614 & 0.78862 \\
\hline V12 & 0.48649 & $\mathbf{0 . 7 6 2 2 2}$ & 0.23473 & 0.76222 \\
\hline V13 & 0.24428 & $\mathbf{0 . 7 7 7 7 6}$ & 0.46529 & 0.77776 \\
\hline V14 & -0.02265 & $\mathbf{0 . 8 1 7 4 4}$ & 0.16495 & 0.81744 \\
\hline V16 & 0.62252 & -0.10363 & -0.50348 & 0.62252 \\
\hline V17 & 0.50012 & -0.59878 & 0.20583 & 0.59878 \\
\hline V18 & $\mathbf{0 . 7 0 7 5 9}$ & -0.48038 & 0.35745 & 0.70759 \\
\hline V19 & $\mathbf{0 . 8 0 8 4 1}$ & 0.10852 & -0.04899 & 0.80841 \\
\hline V20 & 0.62298 & 0.38971 & -0.26544 & 0.62298 \\
\hline V22 & $\mathbf{- 0 . 9 2 6 6 9}$ & 0.06124 & 0.16554 & 0.92669 \\
\hline V23 & $\mathbf{- 0 . 9 5 7 6 1}$ & -0.13268 & 0.09045 & 0.95761 \\
\hline V24 & $\mathbf{- 0 . 9 1 8 3 8}$ & -0.24233 & 0.01023 & 0.91838 \\
\hline V27 & $\mathbf{0 . 8 6 5 2 7}$ & 0.17645 & 0.24292 & 0.86527 \\
\hline V28 & $\mathbf{0 . 8 5 5 4 3}$ & 0.07967 & 0.33938 & 0.85543 \\
\hline V29 & $\mathbf{0 . 9 1 8 7 8}$ & 0.16214 & 0.15040 & 0.91878 \\
\hline Minimum value & & & 0.51675 \\
\hline
\end{tabular}

\section{Appendix 37}

Relative variance in case of 20 variables and 4 or 3 factors (PCA) (not included: V3, V6, V10, V11, V15, V18, V21, V25, V26 and V30).

\begin{tabular}{|c|c|c|c|c|}
\hline & PC1 & PC2 & PC3 & PC4 \\
\hline Relative variance & $43.60 \%$ & $23.40 \%$ & $12.00 \%$ & $9.40 \%$ \\
\hline E Relative variance & $43.60 \%$ & $67.00 \%$ & $79.00 \%$ & $88.40 \%$ \\
\hline
\end{tabular}


A New Method in Attribution? Attempts of the Employment of Geometric Morphometrics...

\section{Appendix 38}

Component matrix in case of 20 variables and 4 factors (PCA) (not included: V3, V6, V10, V11, V15, V18, V21, V25, V26 and V30).

\begin{tabular}{|c|c|c|c|c|c|}
\hline \multirow{2}{*}{ Variables } & \multicolumn{4}{|c|}{ Components } & \multirow{2}{*}{$M A X$} \\
\hline & 1 & 2 & 3 & 4 & \\
\hline$V 1$ & 0.74561 & -0.12316 & -0.37462 & 0.47478 & 0.74561 \\
\hline$V 2$ & 0.75172 & -0.12073 & -0.37554 & 0.45550 & 0.75172 \\
\hline$V 4$ & 0.04382 & 0.76347 & 0.60023 & -0.00522 & 0.76347 \\
\hline$V 5$ & 0.06097 & 0.77379 & 0.50102 & -0.25289 & 0.77379 \\
\hline$V 7$ & -0.25181 & -0.61636 & -0.32209 & -0.58258 & 0.61636 \\
\hline$V 8$ & -0.40552 & -0.81178 & 0.04256 & -0.18599 & 0.81178 \\
\hline$V 9$ & -0.53518 & -0.57520 & 0.35391 & 0.25063 & 0.57520 \\
\hline V12 & 0.78921 & 0.43243 & -0.26978 & 0.03852 & 0.78921 \\
\hline$V 13$ & 0.60026 & 0.70424 & -0.21465 & 0.03506 & 0.70424 \\
\hline$V 14$ & 0.34538 & 0.59351 & -0.53291 & 0.07219 & 0.59351 \\
\hline$V 16$ & 0.45252 & -0.67357 & -0.10446 & 0.45516 & 0.67357 \\
\hline$V 17$ & 0.19957 & -0.35722 & 0.65206 & 0.46749 & 0.65206 \\
\hline$V 19$ & 0.76627 & -0.25169 & 0.11068 & -0.36180 & 0.76627 \\
\hline$V 20$ & 0.72047 & -0.18284 & -0.22610 & -0.56138 & 0.72047 \\
\hline$V 22$ & -0.78799 & 0.47382 & -0.17286 & 0.13126 & 0.78799 \\
\hline$V 23$ & -0.90680 & 0.32865 & -0.11365 & 0.11730 & 0.90680 \\
\hline$V 24$ & -0.93442 & 0.18692 & -0.09234 & 0.19286 & 0.93442 \\
\hline$V 27$ & 0.88184 & -0.02090 & 0.29611 & 0.00222 & 0.88184 \\
\hline$V 28$ & 0.84380 & 0.00792 & 0.42292 & -0.02641 & 0.84380 \\
\hline$V 29$ & 0.91074 & -0.11067 & 0.22819 & -0.05750 & 0.91074 \\
\hline \multicolumn{5}{|c|}{ Minimum value } & 0.57520 \\
\hline
\end{tabular}

\section{Appendix 39}

Relative variance with varimax rotation, in case of 20 variables and 4 factors (PCA) (not included: V3, V6, V10, V11, V15, V18, V21, V25, V26 and V30).

\begin{tabular}{|c|c|c|c|c|}
\hline & $R C 1$ & $R C 2$ & $R C 3$ & $R C 4$ \\
\hline Relative variance & $35.80 \%$ & $23.80 \%$ & $16.20 \%$ & $12.60 \%$ \\
\hline E Relative variance & $35.80 \%$ & $59.60 \%$ & $75.80 \%$ & $88.40 \%$ \\
\hline
\end{tabular}




\section{Appendix 40}

Component matrix with varimax rotation, in case of 20 variables and 4 factors (PCA) (not included: V3, V6, V10, V11, V15, V18, V21, V25, V26 and V30).

\begin{tabular}{|c|c|c|c|c|c|}
\hline \multirow{2}{*}{ Variables } & \multicolumn{3}{|c}{ Components with varimax rotation } & \multirow{2}{*}{ MAX } \\
\cline { 2 - 5 } & 1 & 2 & 3 & 4 & \\
\hline V1 & 0.40640 & 0.43262 & $\mathbf{0 . 7 4 2 3 2}$ & 0.18297 & 0.74232 \\
\hline V2 & 0.41663 & 0.43734 & $\mathbf{0 . 7 3 0 9 6}$ & 0.17032 & 0.73096 \\
\hline V4 & 0.02642 & 0.25618 & $\mathbf{- 0 . 7 0 4 9 6}$ & 0.61791 & 0.70496 \\
\hline V5 & 0.08299 & 0.32186 & $\mathbf{- 0 . 8 1 0 3 1}$ & 0.38776 & 0.81031 \\
\hline V7 & 0.02534 & -0.39086 & 0.06363 & $\mathbf{- 0 . 8 5 3 8 1}$ & 0.85381 \\
\hline V8 & -0.06032 & $\mathbf{- 0 . 7 9 0 3 2}$ & 0.18958 & -0.44233 & 0.79032 \\
\hline V9 & -0.26973 & $\mathbf{- 0 . 8 3 5 3 7}$ & 0.14534 & 0.11670 & 0.83537 \\
\hline V12 & 0.46317 & $\mathbf{0 . 7 9 7 3 8}$ & 0.13191 & 0.12799 & 0.79738 \\
\hline V13 & 0.24749 & $\mathbf{0 . 8 8 5 5 7}$ & -0.08990 & 0.22361 & 0.88557 \\
\hline V14 & -0.05383 & $\mathbf{0 . 8 6 5 6 2}$ & 0.09161 & -0.01251 & 0.86562 \\
\hline V16 & 0.39390 & -0.23870 & $\mathbf{0 . 8 0 9 0 1}$ & 0.09964 & 0.80901 \\
\hline V17 & 0.32953 & -0.51903 & 0.19694 & 0.62802 & 0.62802 \\
\hline V19 & $\mathbf{0 . 8 6 9 7 5}$ & 0.08205 & 0.04193 & -0.16944 & 0.86975 \\
\hline V20 & $\mathbf{0 . 7 6 6 5 5}$ & 0.29055 & 0.04205 & -0.49497 & 0.76655 \\
\hline V22 & $\mathbf{- 0 . 8 9 6 4 1}$ & 0.10204 & -0.27746 & 0.04000 & 0.89641 \\
\hline V23 & $\mathbf{- 0 . 9 3 6 3 9}$ & -0.08643 & -0.26961 & -0.00134 & 0.93639 \\
\hline V24 & $\mathbf{- 0 . 9 3 8 7 4}$ & -0.21245 & -0.16511 & 0.01320 & 0.93874 \\
\hline V27 & $\mathbf{0 . 8 5 4 2 3}$ & 0.20418 & 0.08153 & 0.29617 & 0.85423 \\
\hline V28 & $\mathbf{0 . 8 6 3 0 7}$ & 0.14113 & -0.02640 & 0.35515 & 0.86307 \\
\hline V29 & $\mathbf{0 . 8 9 9 6 9}$ & 0.18671 & 0.13379 & 0.18676 & 0.89969 \\
\hline Minimumnnnnnn value & & & & 0.62802 \\
\hline
\end{tabular}


A New Method in Attribution? Attempts of the Employment of Geometric Morphometrics...

\section{Appendix 41}

Component matrix in case of 20 variables and 3 factors (PCA) (not included: V3, V6, V10, V11, V15, V18, V21, V25, V26 and V30).

\begin{tabular}{|c|c|c|c|c|}
\hline \multirow{2}{*}{ Variables } & \multicolumn{3}{|c|}{ Components } & \multirow{2}{*}{$M A X$} \\
\hline & 1 & 2 & 3 & \\
\hline$V 1$ & 0.74561 & -0.12316 & -0.37462 & 0.74561 \\
\hline$V 2$ & 0.75172 & -0.12073 & -0.37554 & 0.75172 \\
\hline$V 4$ & 0.04382 & 0.76347 & 0.60023 & 0.76347 \\
\hline V5 & 0.06097 & 0.77379 & 0.50102 & 0.77379 \\
\hline$V 7$ & -0.25181 & -0.61636 & -0.32209 & 0.61636 \\
\hline$V 8$ & -0.40552 & -0.81178 & 0.04256 & 0.81178 \\
\hline$V 9$ & -0.53518 & -0.57520 & 0.35391 & 0.57520 \\
\hline$V 12$ & 0.78921 & 0.43243 & -0.26978 & 0.78921 \\
\hline$V 13$ & 0.60026 & 0.70424 & -0.21465 & 0.70424 \\
\hline$V 14$ & 0.34538 & 0.59351 & -0.53291 & 0.59351 \\
\hline$V 16$ & 0.45252 & -0.67357 & -0.10446 & 0.67357 \\
\hline$V 17$ & 0.19957 & -0.35722 & 0.65206 & 0.65206 \\
\hline$V 19$ & 0.76627 & -0.25169 & 0.11068 & 0.76627 \\
\hline$V 20$ & 0.72047 & -0.18284 & -0.22610 & 0.72047 \\
\hline$V 22$ & -0.78799 & 0.47382 & -0.17286 & 0.78799 \\
\hline$V 23$ & -0.90680 & 0.32865 & -0.11365 & 0.90680 \\
\hline$V 24$ & -0.93442 & 0.18692 & -0.09234 & 0.93442 \\
\hline$V 27$ & 0.88184 & -0.02090 & 0.29611 & 0.88184 \\
\hline$V 28$ & 0.84380 & 0.00792 & 0.42292 & 0.84380 \\
\hline$V 29$ & 0.91074 & -0.11067 & 0.22819 & 0.91074 \\
\hline \multicolumn{4}{|c|}{ Minimum value } & 0.57520 \\
\hline
\end{tabular}

\section{Appendix 42}

Relative variance with varimax rotation, in case of 20 variables and 3 factors (PCA) (not included: V3, V6, V10, V11, V15, V18, V21, V25, V26 and V30).

\begin{tabular}{|c|c|c|c|}
\hline & $R C 1$ & $R C 2$ & $R C 3$ \\
\hline Relative variance & $39.50 \%$ & $20.90 \%$ & $18.60 \%$ \\
\hline ERelative variance & $39.50 \%$ & $60.40 \%$ & $79.00 \%$ \\
\hline
\end{tabular}




\section{Appendix 43}

Component matrix with varimax rotation, in case of 20 variables and 3 factors (PCA) (not included: V3, V6, V10, V11, V15, V18, V21, V25, V26 and V30).

\begin{tabular}{|c|c|c|c|c|}
\hline \multirow{2}{*}{ Variables } & \multicolumn{3}{|c|}{ Components with varimax } & \multirow{2}{*}{ MAX } \\
\cline { 2 - 5 } & 1 & 2 & 3 & \\
\hline V1 & 0.62857 & 0.49407 & -0.26876 & 0.62857 \\
\hline V2 & 0.63311 & 0.49858 & -0.26698 & 0.63311 \\
\hline V4 & -0.06613 & 0.03215 & $\mathbf{0 . 9 6 9 3 7}$ & 0.96937 \\
\hline V5 & -0.07819 & 0.11551 & $\mathbf{0 . 9 1 3 2 5}$ & 0.91325 \\
\hline V7 & -0.10408 & -0.22823 & -0.69579 & 0.69579 \\
\hline V8 & -0.09017 & -0.66200 & -0.61553 & 0.66200 \\
\hline V9 & -0.21052 & $-\mathbf{0 . 7 9 8 5 7}$ & -0.24595 & 0.79857 \\
\hline V12 & 0.50989 & $\mathbf{0 . 7 5 8 1 3}$ & 0.21885 & 0.75813 \\
\hline V13 & 0.26114 & $\mathbf{0 . 8 0 0 2 5}$ & 0.44016 & 0.80025 \\
\hline V14 & -0.01230 & $\mathbf{0 . 8 6 0 2 8}$ & 0.12371 & 0.86028 \\
\hline V16 & 0.60995 & -0.13357 & -0.52869 & 0.60995 \\
\hline V17 & 0.45976 & -0.58991 & 0.18236 & 0.58991 \\
\hline V19 & $\mathbf{0 . 8 0 8 7 3}$ & 0.08313 & -0.04264 & 0.80873 \\
\hline V20 & 0.66178 & 0.34394 & -0.21770 & 0.66178 \\
\hline V22 & $\mathbf{- 0 . 9 1 7 3 3}$ & 0.08073 & 0.16526 & 0.91733 \\
\hline V23 & $\mathbf{- 0 . 9 6 3 0 1}$ & -0.09289 & 0.08486 & 0.96301 \\
\hline V24 & $\mathbf{- 0 . 9 3 6 0 0}$ & -0.20102 & -0.00939 & 0.93600 \\
\hline V27 & $\mathbf{0 . 8 8 2 9 5}$ & 0.13105 & 0.26264 & 0.88295 \\
\hline V28 & $\mathbf{0 . 8 6 9 7 7}$ & 0.04231 & 0.36419 & 0.86977 \\
\hline V29 & $\mathbf{0 . 9 2 2 4 1}$ & 0.13903 & 0.15361 & 0.92241 \\
\hline Minimum value & & & 0.58991 \\
\hline & & & & \\
\hline & & & \\
\hline
\end{tabular}

\section{Appendix 44}

Relative variance in case of 18 variables and 4 or 3 factors (PCA) (not included: V2, V3, V6, V10, V11, V15, V17, V18, V21, V25, V26 and V30).

\begin{tabular}{|c|c|c|c|c|}
\hline & $P C 1$ & $P C 2$ & $P C 3$ & $P C 4$ \\
\hline Relative variance & $45.40 \%$ & $25.30 \%$ & $10.80 \%$ & $7.90 \%$ \\
\hline$\Sigma$ Relative variance & $45.40 \%$ & $70.70 \%$ & $81.40 \%$ & $89.30 \%$ \\
\hline
\end{tabular}


A New Method in Attribution? Attempts of the Employment of Geometric Morphometrics...

\section{Appendix 45}

Component matrix in case of 18 variables and 4 factors (PCA) (not included: V2, V3, V6, V10, V11, V15, V17, V18, V21, V25, V26 and V30).

\begin{tabular}{|c|c|c|c|c|c|}
\hline \multirow{2}{*}{ Variables } & \multicolumn{4}{|c|}{ Components } & \multirow{2}{*}{$M A X$} \\
\hline & 1 & 2 & 3 & 4 & \\
\hline$V 1$ & 0.69527 & -0.14366 & 0.42580 & -0.48361 & 0.69527 \\
\hline$V 4$ & 0.09037 & 0.79085 & -0.56347 & -0.05966 & 0.79085 \\
\hline$V 5$ & 0.12361 & 0.78088 & -0.46998 & 0.23251 & 0.78088 \\
\hline$V 7$ & -0.24555 & -0.65899 & 0.21081 & 0.63281 & 0.65899 \\
\hline$V 8$ & -0.42491 & -0.79876 & -0.08954 & 0.17035 & 0.79876 \\
\hline$V 9$ & -0.56708 & -0.51638 & -0.37291 & -0.34811 & 0.56708 \\
\hline$V 12$ & 0.79754 & 0.38846 & 0.33811 & 0.01116 & 0.79754 \\
\hline$V 13$ & 0.62129 & 0.67073 & 0.29509 & 0.05184 & 0.67073 \\
\hline V14 & 0.35442 & 0.55865 & 0.63663 & 0.11028 & 0.63663 \\
\hline$V 16$ & 0.39509 & -0.65625 & 0.24159 & -0.46576 & 0.65625 \\
\hline$V 19$ & 0.77545 & -0.30405 & -0.21643 & 0.23279 & 0.77545 \\
\hline$V 20$ & 0.73924 & -0.26716 & 0.08806 & 0.49963 & 0.73924 \\
\hline$V 22$ & -0.77872 & 0.49856 & 0.16001 & -0.03456 & 0.77872 \\
\hline$V 23$ & -0.90066 & 0.36438 & 0.11449 & -0.01035 & 0.90066 \\
\hline$V 24$ & -0.93948 & 0.23150 & 0.09839 & -0.09387 & 0.93948 \\
\hline$V 27$ & 0.88342 & -0.03854 & -0.27110 & -0.11530 & 0.88342 \\
\hline$V 28$ & 0.85278 & -0.00300 & -0.39102 & -0.10461 & 0.85278 \\
\hline$V 29$ & 0.91501 & -0.13510 & -0.17816 & -0.03951 & 0.91501 \\
\hline \multicolumn{5}{|c|}{ Minimum value } & 0.56708 \\
\hline
\end{tabular}

\section{Appendix 46}

Relative variance with varimax rotation, in case of 18 variables and 4 factors (PCA) (not included: V2, V3, V6, V10, V11, V15, V17, V18, V21, V25, V26 and V30).

\begin{tabular}{|c|c|c|c|c|}
\hline & $R C 1$ & $R C 2$ & $R C 3$ & $R C 4$ \\
\hline Relative variance & $38.60 \%$ & $22.70 \%$ & $15.00 \%$ & $13.10 \%$ \\
\hline$\Sigma$ Relative variance & $38.60 \%$ & $61.30 \%$ & $76.20 \%$ & $89.30 \%$ \\
\hline
\end{tabular}




\section{Appendix 47}

Component matrix with varimax rotation, in case of 18 variables and 4 factors (PCA) (not included: V2, V3, V6, V10, V11, V15, V17, V18, V21, V25, V26 and V30).

\begin{tabular}{|c|c|c|c|c|c|}
\hline \multirow{2}{*}{ Variables } & \multicolumn{4}{|c|}{ Components with varimax rotation } & \multirow{2}{*}{$M A X$} \\
\hline & 1 & 2 & 3 & 4 & \\
\hline$V 1$ & 0.44686 & 0.40855 & -0.68582 & 0.28684 & 0.68582 \\
\hline$V 4$ & 0.03010 & 0.13493 & 0.74155 & 0.62103 & 0.74155 \\
\hline$V 5$ & 0.06090 & 0.25938 & 0.83755 & 0.35709 & 0.83755 \\
\hline$V 7$ & -0.01734 & -0.24455 & -0.11973 & -0.93006 & 0.93006 \\
\hline$V 8$ & -0.07442 & -0.68830 & -0.25307 & -0.55880 & 0.68830 \\
\hline$V 9$ & -0.24144 & -0.86528 & -0.19375 & 0.06273 & 0.86528 \\
\hline$V 12$ & 0.45787 & 0.80660 & -0.07087 & 0.19008 & 0.80660 \\
\hline$V 13$ & 0.23652 & 0.87474 & 0.15733 & 0.28245 & 0.87474 \\
\hline$V 14$ & -0.07805 & 0.91951 & -0.04786 & 0.03591 & 0.91951 \\
\hline$V 16$ & 0.41035 & -0.14429 & -0.81943 & 0.03725 & 0.81943 \\
\hline V19 & 0.87494 & 0.07241 & -0.00291 & -0.15502 & 0.87494 \\
\hline$V 20$ & 0.75227 & 0.32432 & -0.01327 & -0.45163 & 0.75227 \\
\hline$V 22$ & -0.89584 & 0.04251 & 0.25670 & 0.10739 & 0.89584 \\
\hline$V 23$ & -0.94214 & -0.11619 & 0.23597 & 0.01922 & 0.94214 \\
\hline$V 24$ & -0.93851 & -0.23839 & 0.12896 & 0.02114 & 0.93851 \\
\hline$V 27$ & 0.86877 & 0.17681 & -0.02547 & 0.28642 & 0.86877 \\
\hline$V 28$ & 0.87509 & 0.10904 & 0.07618 & 0.32803 & 0.87509 \\
\hline$V 29$ & 0.90126 & 0.20792 & -0.09757 & 0.15421 & 0.90126 \\
\hline \multicolumn{5}{|c|}{ Minimum value } & 0.68582 \\
\hline
\end{tabular}


A New Method in Attribution? Attempts of the Employment of Geometric Morphometrics...

\section{Appendix 48}

Component matrix in case of 18 variables and 3 factors (PCA) (not included: V2, V3, V6, V10, V11, V15, V17, V18, V21, V25, V26 and V30).

\begin{tabular}{|c|c|c|c|c|}
\hline \multirow{2}{*}{ Variables } & \multicolumn{3}{|c|}{ Components } & \multirow{2}{*}{$M A X$} \\
\hline & 1 & 2 & 3 & \\
\hline$V 1$ & 0.69527 & -0.14366 & 0.42580 & 0.69527 \\
\hline V4 & 0.09037 & 0.79085 & -0.56347 & 0.79085 \\
\hline V5 & 0.12361 & 0.78088 & -0.46998 & 0.78088 \\
\hline$V 7$ & -0.24555 & -0.65899 & 0.21081 & 0.65899 \\
\hline$V 8$ & -0.42491 & -0.79876 & -0.08954 & 0.79876 \\
\hline$V 9$ & -0.56708 & -0.51638 & -0.37291 & 0.56708 \\
\hline$V 12$ & 0.79754 & 0.38846 & 0.33811 & 0.79754 \\
\hline$V 13$ & 0.62129 & 0.67073 & 0.29509 & 0.67073 \\
\hline$V 14$ & 0.35442 & 0.55865 & 0.63663 & 0.63663 \\
\hline$V 16$ & 0.39509 & -0.65625 & 0.24159 & 0.65625 \\
\hline V19 & 0.77545 & -0.30405 & -0.21643 & 0.77545 \\
\hline$V 20$ & 0.73924 & -0.26716 & 0.08806 & 0.73924 \\
\hline$V 22$ & -0.77872 & 0.49856 & 0.16001 & 0.77872 \\
\hline$V 23$ & -0.90066 & 0.36438 & 0.11449 & 0.90066 \\
\hline$V 24$ & -0.93948 & 0.23150 & 0.09839 & 0.93948 \\
\hline$V 27$ & 0.88342 & -0.03854 & -0.27110 & 0.88342 \\
\hline$V 28$ & 0.85278 & -0.00300 & -0.39102 & 0.85278 \\
\hline$V 29$ & 0.91501 & -0.13510 & -0.17816 & 0.91501 \\
\hline \multicolumn{4}{|c|}{ Minimum value } & 0.56708 \\
\hline
\end{tabular}

\section{Appendix 49}

Relative variance with varimax rotation, in case of 18 variables and 3 factors (PCA) (not included: V2, V3, V6, V10, V11, V15, V17, V18, V21, V25, V26 and V30).

\begin{tabular}{|c|c|c|c|}
\hline & $R C 1$ & $R C 2$ & $R C 3$ \\
\hline Relative variance & $39.60 \%$ & $22.50 \%$ & $19.30 \%$ \\
\hline L Relative variance & $39.60 \%$ & $62.10 \%$ & $81.40 \%$ \\
\hline
\end{tabular}




\section{Appendix 50}

Component matrix with varimax rotation, in case of 18 variables and 3 factors (PCA) (not included: V2, V3, V6, V10, V11, V15, V17, V18, V21, V25, V26 and V30).

\begin{tabular}{|c|c|c|c|c|}
\hline \multirow[t]{2}{*}{ Variables } & \multicolumn{3}{|c|}{$\begin{array}{c}\text { Components with varimax rota- } \\
\text { tion }\end{array}$} & \multirow[t]{2}{*}{$M A X$} \\
\hline & 1 & 2 & 3 & \\
\hline$V 1$ & 0.53207 & 0.53575 & -0.33943 & 0.53575 \\
\hline$V 4$ & -0.01407 & 0.08672 & 0.97129 & 0.97129 \\
\hline$V 5$ & -0.01044 & 0.16150 & 0.90540 & 0.90540 \\
\hline$V 7$ & -0.05823 & -0.33033 & -0.65306 & 0.65306 \\
\hline$V 8$ & -0.07545 & -0.69882 & -0.57666 & 0.69882 \\
\hline$V 9$ & -0.20936 & -0.80505 & -0.18804 & 0.80505 \\
\hline$V 12$ & 0.46820 & 0.81585 & 0.12829 & 0.81585 \\
\hline$V 13$ & 0.22897 & 0.86112 & 0.35918 & 0.86112 \\
\hline$V 14$ & -0.07602 & 0.91430 & 0.03579 & 0.91430 \\
\hline$V 16$ & 0.49891 & -0.01349 & -0.62930 & 0.62930 \\
\hline V19 & 0.85882 & 0.03712 & -0.04074 & 0.85882 \\
\hline$V 20$ & 0.71889 & 0.25271 & -0.21199 & 0.71889 \\
\hline$V 22$ & -0.91057 & 0.02966 & 0.22483 & 0.91057 \\
\hline$V 23$ & -0.95852 & -0.13212 & 0.14439 & 0.95852 \\
\hline$V 24$ & -0.94246 & -0.23460 & 0.05130 & 0.94246 \\
\hline$V 27$ & 0.88082 & 0.19541 & 0.20340 & 0.88082 \\
\hline$V 28$ & 0.87903 & 0.11758 & 0.30597 & 0.87903 \\
\hline$V 29$ & 0.91277 & 0.22118 & 0.07196 & 0.91277 \\
\hline \multicolumn{4}{|c|}{ Minimum value } & 0.53575 \\
\hline
\end{tabular}

\section{Appendix 51}

Relative variance in case of 16 variables and 4 or 3 factors (PCA) (not included: V1, V2, V3, V6, V10, V11, V15, V16, V17, V18, V21, V25, V26 and V30).

\begin{tabular}{|c|c|c|c|c|}
\hline & $P C 1$ & $P C 2$ & $P C 3$ & PC4 \\
\hline Relative variance & $47.60 \%$ & $26.00 \%$ & $4.80 \%$ & $11.30 \%$ \\
\hline SRelative variance & $47.60 \%$ & $73.60 \%$ & $84.90 \%$ & $89.70 \%$ \\
\hline
\end{tabular}


A New Method in Attribution? Attempts of the Employment of Geometric Morphometrics...

\section{Appendix 52}

Component matrix in case of 16 variables and 4 factors (PCA) (not included: V1, V2, V3, V6, V10, V11, V15, V16, V17, V18, V21, V25, V26 and V30).

\begin{tabular}{|c|c|c|c|c|c|}
\hline \multirow{2}{*}{ Variables } & \multicolumn{4}{|c|}{ Components } & \multirow{2}{*}{ MAX } \\
\cline { 2 - 5 } & 1 & 2 & 3 & 4 & \\
\hline V4 & 0.19052 & $\mathbf{0 . 7 3 2 3 2}$ & 0.56441 & 0.21378 & 0.73232 \\
\hline V5 & 0.23628 & $\mathbf{0 . 7 0 4 5 2}$ & 0.36664 & 0.50968 & 0.70452 \\
\hline V7 & -0.27051 & -0.68425 & -0.45013 & 0.43570 & 0.68425 \\
\hline V8 & -0.47493 & $\mathbf{- 0 . 7 7 4 4 6}$ & 0.00115 & 0.13418 & 0.77446 \\
\hline V9 & -0.60943 & -0.46265 & 0.47393 & -0.24999 & 0.60943 \\
\hline V12 & $\mathbf{0 . 8 0 8 3 1}$ & 0.35116 & -0.33075 & -0.13849 & 0.80831 \\
\hline V13 & 0.66479 & 0.63434 & -0.29302 & -0.05127 & 0.66479 \\
\hline V14 & 0.37566 & 0.56574 & -0.62904 & -0.13234 & 0.62904 \\
\hline V19 & $\mathbf{0 . 7 7 0 4 7}$ & -0.41730 & 0.07981 & 0.09887 & 0.77047 \\
\hline V20 & $\mathbf{0 . 7 3 5 0 1}$ & -0.37622 & -0.29419 & 0.33989 & 0.73501 \\
\hline V22 & $\mathbf{- 0 . 7 4 0 1 0}$ & 0.56332 & -0.09197 & 0.05458 & 0.74010 \\
\hline V23 & $\mathbf{- 0 . 8 6 8 5 6}$ & 0.43816 & -0.06103 & 0.09178 & 0.86856 \\
\hline V24 & $\mathbf{- 0 . 9 2 3 0 4}$ & 0.31826 & -0.01931 & -0.01361 & 0.92304 \\
\hline V27 & $\mathbf{0 . 8 7 9 4 6}$ & -0.11582 & 0.26809 & -0.06852 & 0.87946 \\
\hline V28 & $\mathbf{0 . 8 6 0 2 7}$ & -0.08816 & 0.37603 & -0.00644 & 0.86027 \\
\hline V29 & $\mathbf{0 . 9 0 5 7 9}$ & -0.21192 & 0.14185 & -0.09807 & 0.90579 \\
\hline Minimum value & & & & 0.60943 \\
\hline & & & & \\
\hline
\end{tabular}

\section{Appendix 53}

Relative variance with varimax rotation, in case of 16 variables and 4 factors (PCA) (not included: V1, V2, V3, V6, V10, V11, V15, V16, V17, V18, V21, V25, V26 and V30).

\begin{tabular}{|c|c|c|c|c|}
\hline & $R C 1$ & $R C 2$ & $R C 3$ & $R C 4$ \\
\hline Relative variance & $41.60 \%$ & $24.20 \%$ & $14.80 \%$ & $9.20 \%$ \\
\hline$\sum$ Relative variance & $41.60 \%$ & $65.70 \%$ & $80.50 \%$ & $89.70 \%$ \\
\hline
\end{tabular}




\section{Appendix 54}

Component matrix with varimax rotation, in case of 16 variables and 4 factors (PCA) (not included: V1, V2, V3, V6, V10, V11, V15, V16, V17, V18, V21, V25, V26 and V30).

\begin{tabular}{|c|c|c|c|c|c|}
\hline \multirow{2}{*}{ Variables } & \multicolumn{3}{|c|}{ Components with varimax rotation } & \multirow{2}{*}{ MAX } \\
\cline { 2 - 5 } & 1 & 2 & 3 & 4 & \\
\hline V4 & -0.03092 & 0.12743 & $\mathbf{0 . 8 8 6 1 8}$ & -0.36652 & 0.88618 \\
\hline V5 & -0.02879 & 0.24269 & $\mathbf{0 . 9 4 1 1 4}$ & -0.03002 & 0.94114 \\
\hline V7 & -0.04420 & -0.25781 & -0.42806 & $\mathbf{0 . 8 2 5 9 4}$ & 0.82594 \\
\hline V8 & -0.07454 & -0.68320 & -0.43849 & 0.42281 & 0.68320 \\
\hline V9 & -0.21442 & $\mathbf{- 0 . 8 5 0 0 5}$ & -0.24417 & -0.21064 & 0.85005 \\
\hline V12 & 0.47510 & $\mathbf{0 . 8 1 0 3 6}$ & 0.06315 & -0.13736 & 0.81036 \\
\hline V13 & 0.23323 & $\mathbf{0 . 8 7 7 3 9}$ & 0.27493 & -0.18177 & 0.87739 \\
\hline V14 & -0.06310 & $\mathbf{0 . 9 3 0 4 4}$ & -0.04248 & -0.05368 & 0.93044 \\
\hline V19 & $\mathbf{0 . 8 6 9 3 0}$ & 0.05656 & -0.01729 & 0.15724 & 0.86930 \\
\hline V20 & $\mathbf{0 . 7 3 1 3 7}$ & 0.29449 & -0.06500 & 0.50795 & 0.73137 \\
\hline V22 & $\mathbf{- 0 . 9 1 2 2 8}$ & 0.04003 & 0.18871 & -0.08389 & 0.91228 \\
\hline V23 & $\mathbf{- 0 . 9 6 2 5 1}$ & -0.11595 & 0.13587 & -0.01413 & 0.96251 \\
\hline V24 & $\mathbf{- 0 . 9 4 5 9 9}$ & -0.23148 & 0.02011 & -0.07045 & 0.94599 \\
\hline V27 & $\mathbf{0 . 8 7 7 2 3}$ & 0.17032 & 0.17855 & -0.18170 & 0.87723 \\
\hline V28 & $\mathbf{0 . 8 7 1 9 9}$ & 0.10174 & 0.28737 & -0.18969 & 0.87199 \\
\hline V29 & $\mathbf{0 . 9 1 4 0 3}$ & 0.21217 & 0.04054 & -0.11400 & 0.91403 \\
\hline Minimum value & & & & 0.68320 \\
\hline & & & & & \multirow{2}{*}{ V8 } \\
\hline
\end{tabular}


A New Method in Attribution? Attempts of the Employment of Geometric Morphometrics...

\section{Appendix 55}

Component matrix in case of 16 variables and 3 factors (PCA) (not included: V1, V2, V3, V6, V10, V11, V15, V16, V17, V18, V21, V25, V26 and V30).

\begin{tabular}{|c|c|c|c|c|}
\hline \multirow{2}{*}{ Variables } & \multicolumn{3}{|c|}{ Components } & \multirow{2}{*}{ MAX } \\
\cline { 2 - 4 } & 1 & 2 & 3 & \\
\hline V4 & 0.19052 & $\mathbf{0 . 7 3 2 3 2}$ & 0.56441 & 0.73232 \\
\hline V5 & 0.23628 & $\mathbf{0 . 7 0 4 5 2}$ & 0.36664 & 0.70452 \\
\hline V7 & -0.27051 & -0.68425 & -0.45013 & 0.68425 \\
\hline V8 & -0.47493 & $\mathbf{- 0 . 7 7 4 4 6}$ & 0.00115 & 0.77446 \\
\hline V9 & -0.60943 & -0.46265 & 0.47393 & 0.60943 \\
\hline V12 & $\mathbf{0 . 8 0 8 3 1}$ & 0.35116 & -0.33075 & 0.80831 \\
\hline V13 & 0.66479 & 0.63434 & -0.29302 & 0.66479 \\
\hline V14 & 0.37566 & 0.56574 & -0.62904 & 0.62904 \\
\hline V19 & $\mathbf{0 . 7 7 0 4 7}$ & -0.41730 & 0.07981 & 0.77047 \\
\hline V20 & $\mathbf{0 . 7 3 5 0 1}$ & -0.37622 & -0.29419 & 0.73501 \\
\hline V22 & $\mathbf{- 0 . 7 4 0 1 0}$ & 0.56332 & -0.09197 & 0.74010 \\
\hline V23 & $\mathbf{- 0 . 8 6 8 5 6}$ & 0.43816 & -0.06103 & 0.86856 \\
\hline V24 & $\mathbf{- 0 . 9 2 3 0 4}$ & 0.31826 & -0.01931 & 0.92304 \\
\hline V27 & $\mathbf{0 . 8 7 9 4 6}$ & -0.11582 & 0.26809 & 0.87946 \\
\hline V28 & $\mathbf{0 . 8 6 0 2 7}$ & -0.08816 & 0.37603 & 0.86027 \\
\hline V29 & $\mathbf{0 . 9 0 5 7 9}$ & -0.21192 & 0.14185 & 0.90579 \\
\hline Minimum value & & & 0.60943 \\
\hline & & & & \\
\hline
\end{tabular}

\section{Appendix 56}

Relative variance with varimax rotation, in case of 16 variables and 3 factors (PCA) (not included: V1, V2, V3, V6, V10, V11, V15, V16, V17, V18, V21, V25, V26 and V30).

\begin{tabular}{|c|c|c|c|}
\hline & $R C 1$ & $R C 2$ & $R C 3$ \\
\hline Relative variance & $41.60 \%$ & $23.00 \%$ & $20.30 \%$ \\
\hline E Relative variance & $41.60 \%$ & $64.60 \%$ & $84.90 \%$ \\
\hline
\end{tabular}




\section{Appendix 57}

Component matrix with varimax rotation, in case of 16 variables and 3 factors (PCA) (not included: V1, V2, V3, V6, V10, V11, V15, V16, V17, V18, V21, V25, V26 and V30).

\begin{tabular}{|c|c|c|c|c|}
\hline \multirow{2}{*}{ Variables } & \multicolumn{3}{|c|}{ Components with varimax rota- } & \multirow{2}{*}{ MAX } \\
\cline { 2 - 4 } & 1 & 2 & 3 & \\
\hline V4 & -0.04322 & 0.07815 & $\mathbf{0 . 9 3 9 7 7}$ & 0.93977 \\
\hline V5 & -0.03317 & 0.22465 & $\mathbf{0 . 7 9 6 8 9}$ & 0.79689 \\
\hline V7 & -0.02343 & -0.16985 & $\mathbf{- 0 . 8 4 5 3 4}$ & 0.84534 \\
\hline V8 & -0.06413 & -0.63198 & -0.64949 & 0.64949 \\
\hline V9 & -0.22010 & $\mathbf{- 0 . 8 6 1 7 4}$ & -0.13790 & 0.86174 \\
\hline V12 & 0.47325 & $\mathbf{0 . 7 9 0 0 1}$ & 0.19494 & 0.79001 \\
\hline V13 & 0.22960 & $\mathbf{0 . 8 5 0 3 4}$ & 0.39296 & 0.85034 \\
\hline V14 & -0.06209 & $\mathbf{0 . 9 2 1 6 6}$ & 0.05973 & 0.92166 \\
\hline V19 & $\mathbf{0 . 8 7 2 9 5}$ & 0.06784 & -0.08655 & 0.87295 \\
\hline V20 & $\mathbf{0 . 7 4 4 0 4}$ & 0.33997 & -0.31490 & 0.74404 \\
\hline V22 & $\mathbf{- 0 . 9 1 4 7 5}$ & 0.03303 & 0.18888 & 0.91475 \\
\hline V23 & $\mathbf{- 0 . 9 6 3 4 3}$ & -0.11440 & 0.09391 & 0.96343 \\
\hline V24 & $\mathbf{- 0 . 9 4 7 9 8}$ & -0.23318 & 0.02507 & 0.94798 \\
\hline V27 & $\mathbf{0 . 8 7 2 2 8}$ & 0.14520 & 0.27709 & 0.87228 \\
\hline V28 & $\mathbf{0 . 8 6 6 2 1}$ & 0.07457 & 0.36517 & 0.86621 \\
\hline V29 & $\mathbf{0 . 9 1 1 3 8}$ & 0.19531 & 0.12936 & 0.91138 \\
\hline Minimum value & & & 0.64949 \\
\hline
\end{tabular}

\section{Appendix 58}

Relative variance in case of 14 variables and 4 or 3 factors (PCA) (not included: V1, V2, V3, V6, V8, V10, V11, V15, V16, V17, V18, V21, V23, V25, V26 and V30).

\begin{tabular}{|c|c|c|c|c|}
\hline & $P C 1$ & $P C 2$ & $P C 3$ & PC4 \\
\hline Relative variance & $47.50 \%$ & $24.30 \%$ & $12.90 \%$ & $5.30 \%$ \\
\hline E Relative variance & $47.50 \%$ & $71.80 \%$ & $84.70 \%$ & $90.00 \%$ \\
\hline
\end{tabular}


A New Method in Attribution? Attempts of the Employment of Geometric Morphometrics...

\section{Appendix 59}

Component matrix in case of 14 variables and 4 factors (PCA) (not included: V1, V2, V3, V6, V8, V10, V11, V15, V16, V17, V18, V21, V23, V25, V26 and V30).

\begin{tabular}{|c|c|c|c|c|c|}
\hline \multirow{2}{*}{ Variables } & \multicolumn{4}{|c|}{ Components } & \multirow{2}{*}{ MAX } \\
\cline { 2 - 5 } & 1 & 2 & 3 & 4 & \\
\hline V4 & 0.19096 & $\mathbf{0 . 7 4 4 8 4}$ & 0.55403 & 0.20096 & 0.74484 \\
\hline V5 & 0.25032 & $\mathbf{0 . 7 2 9 2 8}$ & 0.35914 & 0.47848 & 0.72928 \\
\hline V7 & -0.25829 & -0.67738 & -0.43865 & 0.44530 & 0.67738 \\
\hline V9 & -0.62664 & -0.44961 & 0.47244 & -0.22589 & 0.62664 \\
\hline V12 & $\mathbf{0 . 8 0 9 3 3}$ & 0.34280 & -0.32985 & -0.15955 & 0.80933 \\
\hline V13 & 0.67335 & 0.63166 & -0.29730 & -0.08375 & 0.67335 \\
\hline V14 & 0.38383 & 0.55759 & -0.63595 & -0.15478 & 0.63595 \\
\hline V19 & $\mathbf{0 . 7 6 5 8 5}$ & -0.42406 & 0.09524 & 0.10371 & 0.76585 \\
\hline V20 & $\mathbf{0 . 7 3 7 3 9}$ & -0.39517 & -0.27789 & 0.35313 & 0.73739 \\
\hline V22 & $\mathbf{- 0 . 7 3 4 3 3}$ & 0.55997 & -0.10841 & 0.06684 & 0.73433 \\
\hline V24 & $\mathbf{- 0 . 9 1 8 1 2}$ & 0.32189 & -0.03381 & -0.00124 & 0.91812 \\
\hline V27 & $\mathbf{0 . 8 7 6 9 8}$ & -0.12098 & 0.28003 & -0.09482 & 0.87698 \\
\hline V28 & $\mathbf{0 . 8 6 0 8 3}$ & -0.09007 & 0.38822 & -0.04008 & 0.86083 \\
\hline V29 & $\mathbf{0 . 9 0 3 6 8}$ & -0.21220 & 0.15476 & -0.12611 & 0.90368 \\
\hline Minimum value & & & & 0.62664 \\
\hline
\end{tabular}

\section{Appendix 60}

Relative variance with varimax rotation, in case of 14 variables and 4 factors (PCA) (not included: V1, V2, V3, V6, V9, V10, V11, V15, V16, V17, V18, V21, V24, V25, V26 and V30).

\begin{tabular}{|c|c|c|c|c|}
\hline & $R C 1$ & $R C 2$ & $R C 3$ & $R C 4$ \\
\hline Relative variance & $40.70 \%$ & $24.20 \%$ & $15.80 \%$ & $9.20 \%$ \\
\hline SRelative variance & $40.70 \%$ & $64.90 \%$ & $80.70 \%$ & $90.00 \%$ \\
\hline
\end{tabular}




\section{Appendix 61}

Component matrix with varimax rotation, in case of 14 variables and 4 factors (PCA) (not included: V1, V2, V3, V6, V8, V10, V11, V15, V16, V17, V18, V21, V23, V25, V26 and V30).

\begin{tabular}{|c|c|c|c|c|c|}
\hline \multirow{2}{*}{ Variables } & \multicolumn{3}{|c}{ Components with varimax rotation } & \multirow{2}{*}{ MAX } \\
\cline { 2 - 5 } & 1 & 2 & 3 & 4 & \\
\hline V4 & -0.00655 & 0.10100 & $\mathbf{0 . 9 0 0 0 0}$ & 0.34402 & 0.90000 \\
\hline V5 & -0.01037 & 0.22901 & $\mathbf{0 . 9 4 8 2 2}$ & 0.02773 & 0.94822 \\
\hline V7 & -0.06845 & -0.23347 & -0.45133 & $\mathbf{- 0 . 8 0 8 3 2}$ & 0.80832 \\
\hline V9 & -0.21398 & $\mathbf{- 0 . 8 4 7 4 8}$ & -0.24997 & 0.20628 & 0.84748 \\
\hline V12 & 0.46762 & $\mathbf{0 . 8 1 4 5 2}$ & 0.07624 & 0.13735 & 0.81452 \\
\hline V13 & 0.23421 & $\mathbf{0 . 8 7 7 3 7}$ & 0.29375 & 0.19204 & 0.87737 \\
\hline V14 & -0.07433 & $\mathbf{0 . 9 3 5 4 1}$ & -0.01775 & 0.07610 & 0.93541 \\
\hline V19 & $\mathbf{0 . 8 6 3 6 2}$ & 0.06275 & -0.03581 & -0.18738 & 0.86362 \\
\hline V20 & $\mathbf{0 . 7 1 7 4 1}$ & 0.29687 & -0.08439 & -0.54026 & 0.71741 \\
\hline V22 & $\mathbf{- 0 . 9 0 2 9 5}$ & 0.01997 & 0.21212 & 0.09122 & 0.90295 \\
\hline V24 & $\mathbf{- 0 . 9 3 7 9 9}$ & -0.24259 & 0.03755 & 0.08725 & 0.93799 \\
\hline V27 & $\mathbf{0 . 8 8 7 2 7}$ & 0.17285 & 0.15970 & 0.16881 & 0.88727 \\
\hline V28 & $\mathbf{0 . 8 8 8 0 5}$ & 0.10319 & 0.26432 & 0.17975 & 0.88805 \\
\hline V29 & $\mathbf{0 . 9 1 5 8 4}$ & 0.22430 & 0.02298 & 0.10922 & 0.91584 \\
\hline Minimum value & & & & 0.71741 \\
\hline
\end{tabular}

\section{Appendix 62}

The reliability of the cluster analysis in case of landmark configuration.

\begin{tabular}{|c|c|c|c|c|c|c|c|c|}
\hline \multirow{2}{*}{$\begin{array}{c}\text { Distance } \\
\text { between the } \\
\text { clusters }\end{array}$} & \multicolumn{6}{|c|}{ Distance between the pieces inside the clusters } & \multirow{2}{*}{$\begin{array}{c}\text { Distance } \\
\text { between each } \\
\text { piece without the } \\
\text { cluster } \\
\text { procedure }\end{array}$} & \multirow{2}{*}{$\begin{array}{c}\text { Reliability } \\
\text { of the } \\
\text { clustering }\end{array}$} \\
\hline & 1 & 2 & 3 & 4 & 5 & 6 & & \\
\hline 78.50095 & 1.197566 & 7.062644 & 7.613357 & 4.048987 & 8.594415 & 8.982078 & 116 & $67.67 \%$ \\
\hline
\end{tabular}

